\title{
SHOULD THE STAGNANT HOMEOWNERSHIP RATE BE A SOURCE OF CONCERN?
}

\author{
Richard K. Green
}

Working Paper No. 5176

\author{
NATIONAL BUREAU OF ECONOMIC RESEARCH \\ 1050 Massachusetts Avenue \\ Cambridge, MA 02138 \\ July 1995
}

Originally prepared for NBER Conference on Public Economics and Housing, Kiawah Island, South Carolina, October 20-22, 1994. The author gratefully acknowledges support from the University of Wisconsin Graduate School, helpful research assistance from Tim Craft, and comments from Pat Hendershott, Anne Schnare, Peter Englund, Chris Meyer, Gary Engelhardt, and NBER Summer Workshop and Conference participants. Thanks also go to the University of Wisconsin Center for Demography and Ecology, which provided computer resources and some of the data used in this paper. The usual caveat applies. This paper was prepared as part of the NBER Study on Housing Dynamics and was presented at the NBER Study Conference. Any opinions expressed are those of the author and not those of the National Bureau of Economic Research.

(c) 1995 by Richard K. Green. All rights reserved. Short sections of text, not to exceed two paragraphs, may be quoted without explicit permission provided that full credit, including () notice, is given to the source. 


\title{
SHOULD THE STAGNANT HOMEOWNERSHIP RATE BE A SOURCE OF CONCERN?
}

\begin{abstract}
The homeownership rate in the United States was essentially stagnant during the 1980's. This stagnation should be a source of concern if the rate reflects stagnant economic conditions and ownership opportunities, not if it simply reflects changing demographic conditions or preferences.

Using a series of affordability measures, we find that homeownership opportunities improved almost everywhere during the 1980's, suggesting that the cause of the stagnant rate was something other than economic conditions. In fact, we find that both demographics and changes in preferences led to an increase in the proportion of households headed by single people; all else being equal, this would tend to push the owner-occupancy rate downward. We also found that while homeownership opportunities improved during the 1980's, the ex ante use cost of owning a home increased almost everywhere, reducing the financial attractiveness of owning a home. The combination of improving affordability conditions and worsening financial appeal had an overall neutral effect on the aggregate ownership rate.
\end{abstract}

Richard K. Green

School of Business

University of Wisconsin-Madison

975 University Avenue

Madison, WI 53706 
Should the Stagnant Homeownerehip Rate be a Source of Concern?

by Richand K. Green

University of Wisconsin-Madison

May 1995

\section{Intraduction}

The aggregate homoownorship rate in the United States fell mimitely from 64.4 porcent in 1980 to 64.2 porcent in 1990. Moro rocent Census data show that the homeownership rate has risen, but only by a little bit, since 1990. Thus the overall picture that emerges from recent history suggests that the homoownership rate is stagnent, rather than growing. This stands in contrast most of the post-World War II period, when the United States homeownership rate grow rapidly.

Housing activists, the popular press, and some scholars have suggested that the trajectory of the ownership rate should be a source of concern. This concern arose in part because data from the Current Population Reports during the 1980 s suggested that the rate actually declined by more than 0.2 percent over tho decade. Presumably, by virtue of its large sample size, the Census is a more reliable data source. A more valid concorn is the decline in the homeownerahip rate among young married couples in most states between 1980 and 1990. The overall ownership rate remained steady during the decade only because the rate among those over 65 increased nearly everywhere. Thus the flat aggregate rate could be hiding a deterioration of affordability conditions for traditional first-timo homebuying groups, suggesting that the current stagnation may be a prolude to a substantial drop in the homeowning rate in the years to como. Indeed, the very title of one study, Myers, et al. (1992), "Retreat from Homeownership," suggests an imminent implosion in the percentage of bouseholds that are homeowners. 
Policymakens have taken note of tho alurums over the (escentially) unmoving overall rate. Former House Banking Committoo chairman Henry Gonzales has called for downpayment assistance programs to bring access to homeownorship to greater mumbers of families in H.R. 67, 103rd Congress, and the Clinton Administration Department of Housing and Urban Development has floated proposals to allow lower downpayments for FHA mortgages so as to achieve the goal of a highor homeownership rato (Stogman (1994)). The secondary mortgage market agencies have also come under increasing pressure to loosen underwriting standards so that it will become easier for renting households to becomo homoowning housoholds (Van Order and Schnare (1994).

But before worrying too much about the stagnant homeownenship rate, we should answer some fundamental quections: is the homeownership rate a reflection of economic opportunity, and is the atagnant rate therefore indicative of a stagnant economy? How much is the homeowning rate simply a function of demographics and household types? How much might changing tastes explain the changing homeownership rate?

The answers to these questions will help determine whether the stagnant homoownership rate should be a sourco of concern. For instance, if the rate reflects the economy, and is not moving largely because of "affordability" problems (as, for example, Joint Center for Housing Studies (1988-1992) maintained), then the fact that the rate is not growing should be cause for concern. If the rate reflects changes in what I'll call "pure demographics" - demographic characteristics over which people have no comtrol, such as age and race - then we needn't worry about it. Finally, if the rate reflects changes in "economic demographics"--such as bousohold typo-then we will need to try and disentangle whether it is the economics or the demographics that are responsible for stagnation. As Hendershott (1988) notes, the homoownorship rate varios significantly with marital status. Bocker 
(1991) auggests that marrying, divorcing, and having children are very much economic, as well as demographic, decisions. Thus to find how the economy has affected the homeownorship rate, wo must first look at how demographic conditions alone have affected the choice of household type, and then how temuro-choice decisions are made within each household type. 1 Wo must also consider the impact of changing tastes.

This paper seolcs to begin to answer the questions above, and is organized as follows. Section 2 examines how homeowning opportunitios changed between 1980 and 1990 by developing some new measures of housing affordability and then applying them to those two census years. As a test of the usefulness of these measures, the paper also examines how well thoy help predict rates of state ownership. Section 3 examines bow housebolds choose to form into various types (married, married with children, single, and singles with children). Section 4 then looles at how temure choice decisions are made within each household type. Finally, Section 5 compares how the change in the actual homeownership rate between 1980 and 1990 differed from what the analysis in Sections (2) through (4) predicted, and considers the implications of this difference.

\section{Measures of affordability}

A. Affordability and Tenure Choice Theory

When choosing the amount and form of their housing, households maximize the utility function:

$$
u=\sum_{t=1}^{\infty} \beta^{t} u_{r}\left(X_{r} \max \left[g\left(h_{n}\right), k\left(h_{o}\right)\right]\right)
$$

1 The homeownership rate is also of somo intrinsic interest: Green and Whito (1994) and Galeter (1983) have shown that homeowning produces some positive externalities for children and for the bousing stock, respectively. 
where $u_{4}$ is a valid utility function, $X$ is a numeraire good, $h_{3}$ is a quantity of rental housing service, $h_{0}$ is a quantity of owner cocupied housing service, and $g$ and $k$ map the two kinds of housing services into utility. For simplicity, we assume that the housing choice represents a choice of primary residence, and lump other residences into the ' $\mathrm{X}$ ' good. Thus if one chooses to be an owneroccupier, the implication is that consumption of rental housing for a principal residence would produce no marginal utility. $\beta$ indicates consumer time preference, and is of course less than one. Naturally, there is also an implicit assumption that owner and rental occupied housing are differentiated products from one another. The household must then maximize its utility function subject to the intertemporal budget constraint:

$$
\sum_{t=1}^{\infty} \frac{Y_{t}}{\left(1+r_{t}\right)^{t}} \geq \sum_{t=1}^{\infty} \frac{\left(X_{t}+u c_{t} * h_{\alpha t}+r e n t_{t} * h_{n}\right)}{\left(1+r_{t}\right)^{t}}
$$

where $Y_{t}$ is after-tax income excluding the impact of mortgage interest and property tax deductions at time $t, r_{t}$ is the after-tax opportunity cost of capital, uc, is the user cost of owner occupied housing after tax deductions at time $t$, and rent is the cost per unit of rental housing services at time $t$. The budget constraint simply says that the present value of the consumption stream must be no more than the present value of the income stream. Opportunity cost can vary with time period because different types of borrowing and investing are treated differently for tax purposes. ${ }^{2}$

But households also face underwriting constraints: at the time they decide to purchase a house, they are not allowed to spend more than a fixed

2 For a full discussion of the implications of tax dectuctions on user cost and the budget constraint, soo Hendershott and Slemrod (1983). 
percentage their incomes of principal, interest and tax payments. They must also accumulate a minimum downpayment to purchase a bouse: typically, even for an FHA mortgage, households must accumulate three percent of the value of the house they wish to purchase. ${ }^{3}$ Earlier analyses (e.g. Zorn (1989) and Linneman and Wachter (1989)) have shown that these constraints matter, and prevent people from consuming their "optimal" level of housing. From an economic perspective, therefore, tenure choice is a function of: the financial attractiveness of owning relative to renting (the utility function specified in (1) and the constraint specified in (2)); principal, interest, tax and insurance payment to income ratios; and house price-to-income ratios (this reflects the onerousness of the downpayment requirement).

Presumably, rent-to-income ratios also have some impact on the ability of households to accumulate the savings necessary to make a down payment, and therefore could also have an effect on the overall ownership rate. However, as rent-to-income ratios rise, owner-occupied housing also becomes relatively more attractive financially, and households will have greater incentives to become owners. Thus if a rent-to-income ratio is used as an affordability measure, we must recognize that its income and substitution effects move in opposite directions.

\section{B. Index Definitions}

Perhaps the most commonly cited measure of housing affordability is the National Association of REALTORS Housing Affordability Index. This index is the percentage of the median priced house a median income family of four can afford given Fannie Mae/Freddie Mac underwriting standards and current interest rates.

I For very modestly priced houses, the downpayment requirement is a little smaller than this. 
While the index is useful for identifying trends, it has a number of limitations. First, by focussing on the median family of four, the index includes households who are already homeowners. These households have already overcome any "affordability barriers" to homeownership, and are therefore not really germane to any discussion about affordability constraints to the tenure choice decision. Second, an increasingly large number of households are not made up of families of four, and so the affordability conditions faced by such households are decreasingly representative of general affordability conditions. Third, the first-time homebuyer will most likely not buy the median priced house. Fourth, the housing affordability index looks only at payment-to-income ratios, and does not consider the barrier that accumulating a downpayment might present to potential homeowners. Finally, a national index cannot represent how homeownership opportunities vary in different parts of the country. The national housing affordability index may seem favorable, but renter households in California, New England, and New York might still be shut out of the owner-occupied housing market.

To overcome these limitations, I create four different measures of housing affordability. Each of these indexes is calculated for all $\mathbf{5 0}$ states for the years 1980 and $1990 .^{4}$ The data underlying the indexes come from the Public Use Micro-sample of the 1980 and 1990 censuses of the United States. The first three capture the liquidity constraints discussed above; the fourth depicts the financial attractiveness of owning.

The first has some features in common with the NAR index: it is a payment-to-income ratio (PIR) index. The PIR index has substantial

4 Even states are often large and diverse, of course: the housing markets in Now York City and Buffalo aro quite different, us aro tho markets in San Francisco and Bakersfield. Nevertheless, by focussing on states, we narrow our goographic ground considerably, and we aro ablo to cover the country comprehensively (something that metropolitan areas, for example, do not allow us to do). 
differences from the NAR index, however. First, the index calculates the monthly principal and interest payments on a thirty year mortgage with a 90 percent loan-to-value ratio on a house priced at the 25 th percentile. While this percentile is arbitrary, it also more closely resembles the price point at which a first-time buyer will purchase a house. Second, the index employs for its income data the median income for all renter households. Renters are the only households that have been potentially denied homeowning opportunities; the incomes of renter households are therefore the only relevant incomes to discussions of homeowning opportunities. Finally, the PIR index adds property taxes to principal and interest payments to come up with a total monthly payment; the NAR index looks only at principal and interest. The property tax on a house at the 25 th percentile is again calculated from data in the public use micro-sample. This index thus reflects the position of households relative to Fannie Mae-Freddie Mac underwriting standards. Ideally, we would also add the costs of private mortgage insurance (because we are looking at 90 percent loan-to-value ratio loans) and hazard insurance, but we do not have good stateby-state data on these items. However, as we shall later see, this omission is inconsequential to the outcome of our analysis.

The second and third indexes attempt to get some sense of the onerousness of the downpayment burden on renter households. The second index is simply a house-price to income ratio (again, based upon median renter income and a house priced at the 25 th percentile). Assuming homebuyers must have ten percent of the value of a house in cash in order to purchase a house, this index, when multiplied by ten percent, represents the fraction of annual income the median renter household requires in order to purchase a house at the 25 th percentile of the price distribution. The third index is a rent-to-income

${ }^{3}$ See NAR (1992) for some evidence about house prices paid by the typical first time homebuyer. 
index, representing the percentage the median income renter houschold must spend in gross rent on the median rental unit. This measure differs from looking at the more typical median rent-to-income ratio, because it avoids one important endogeneity problem: that there could be households with strong tastes for housing. If households choose to spend a large fraction of income on rental housing, but have inexpensive housing available to them, their high rentto-income ratios do not reflect an affordability problem.

Finally, I create an index that reflects the financial desirability of owning a home: a service-flow-cost to income ratio. To calculate this index, I use the well-known formula for user cost as employed in Green and Hendershott (1993), among other places:

$$
u c=\left(1-\tau_{Y}\right) R m+\left(1-\tau_{Y}\right) i(1-m)+p-\pi+\tau_{p}\left(1-\tau_{Y}\right)+d
$$

where uc is user cost, $\tau_{Y}$ is the marginal income tax rate, $R$ is the mortgage interest rate, $m$ is the loan-to-value ratio, $i$ is the opportunity cost of capital, $\rho$ is maintenance cost and depreciation, $\pi$ is expected house price appreciation, $\tau_{p}$ is the property tax rate, and $d$ is a risk premium. For each state, we calculated the marginal federal and state tax rate for the median renter's income, assuming that the household was headed by a married couple and that it itemized. We took mortgage rates for 1980 and 1990 from the Federal Home Loan Bank Board survey. We assumed the loan to value ratio was 0.75 , and used the ten-year Treasury Bond rate for 1980 and 1990 as our measure of opportunity cost. We put maintenance expenses at 0.02 and the risk premium at 0.03 , and calculate property tax rates on a state-by-state basis using reports of owners whose house

- All of the indexes involving house prices are calculated using owners' estimates of value. While these estimates can be biased (see Goodman and Ittner (1992) for some estimates and a literature review), the bias never seems to be systematic, and therefore not a major source of concern when we compare index numbers from one year to another. 
price is at the 25 th percentile.

Finally, to calculate inflation, we use two measures: a crude measure of expected inflation that follows the adaptive inflationary expectations hypothesis, and a measure of how much it actually cost bouseholds to live in their houses.

For each state with a city included in the National Association of Realtors Existing Home Sales data base, we take as expected house price inflation the average percentage increase in house prices in the state's largest city for the three years preceding the index year. For example, for Illinois in 1980 , we use as expected inflation the average house price inflation rate in Chicago for the years 1977-1980. For states without cities in the NAR database, we use the average rate of house price appreciation for the census region in which the state lies: this rate is calculated by the U.S. Department of Commerce.

To get our measure of actual user cost (i.e., the actual cost of owning the home), we use the same databases and technique as we use to calculate a rate of anticipated inflation, except that we take the average increase in house price for the three years following the index year.

User cost based upon an average ex ante inflation rate may be viewed as a measure of the anticipated financial benefits of purchasing a house. User cost based upon an ex post rate, of course, is a measure of how beneficial the homeowning decision actually turned out to be. ${ }^{7}$

C. Index Results: Liquidity Constraints.

\section{Changes in Opportunities}

Generally speaking, the news about the change in homeowning

1 Ideally wo would estimate a more sophisticated empirical model of inflationary expectations. Unfortunately, a paucity of data from earlior in the 1970s provents us from doing this. 
opportunities between 1980 and 1990 is not at all bad. By our three liquidity measures, in fact, homeowning opportunities for median income renter households generally improved over the period 1980-1990.

Median gross rent to median income ratios improved in 30 of 50 states. Thus, based upon changes from 1980 to 1990 , it would be difficult to make a case that rental affordability conditions have generally deteriorated for median income rental households (see figure 1). And as we will see below, there appears to be a sufficient stock of affordable rental housing for the median renter: the "middle" of the housing market appears to be just fine.

House price-to-income ratios (using house prices at the 25th percentile, an arbitrary but not unreasonable place to put the first-time homebuyer's price) improved in 41 of the 50 states (see figure 2). Note that all states where conditions worsened are in the Northeast. Myers et al. (1992) show that the homeownership rate actually rose in most of these states. As with rent-to-income, one would be hard pressed to make a case that higher house price-to-income ratios impeded homeowning opportunities between 1980 and 1990.

The change in the ratio of principal, interest and property tax payments to income improved in 47 states between 1980 and 1990 . The generally falling house price-to-income ratios were reinforced by lower mortgage interest rates in 1990 than in 1980 (see figure 3). This ratio does exclude private mortgage insurance and hazard insurance premiums. The Mortgage Guarantee Insurance Corporations rate schedule suggests that a typical annual premium for a 90 percent loan to-value borrower would be 50 basis points per year. Even if the premium rose from nothing in 1980 to 50 basis points in 1990, PITI ratios would have improved in 46 of the 50 states".

- The editor provided me with MGIC's Ohio premimum schectules for 1980 and 1990. The annual premium for 90 percent LTV loans increased 11 basis points over that timo period. 
As for homeowners insurance, according to the Department of Commerce, the value of homeowning insurance premiums per household rose by 1.5 percent per year between 1987 (the earliest year for which the data are reported) and 1990. This rate is substantially lower than the rate of nominal income growth. So once again, one would be hard pressed to make the case that homeowning affordability conditions general worsened from 1980 to 1990 .

\section{Levels of Opportunity}

Although the primary purpose of this paper is to investigate changes in the conditions affecting homeownership, context is important, and so figures 4-6 report levels of affordability conditions in 1990.

In all 50 states, the median gross rent to median income ratio was below 30 percent in 1990, indicating that rental housing was generally affordable for median income renter households. However, this interpretation presumes appropriate sorting -- that the lowest income household takes the lowest priced rental unit, that the second lowest income household takes the second lowest priced unit, and so on. For states with median gross rent to median income ratios approaching 30 percent, even median income rental households may be facing a rental affordability problem, meaning that accumulating funds for a downpayment would be difficult. Nevertheless, the data hardly imply a rental affordability "crisis" from those in the middle of the renter income distribution.

In 1990, the house price-to- income ratio was greater than three in eight states. House price-to-income ratios give a sense of the dowmpayment burden relative to incomes. If a minimum downpayment of 10 percent is required for a conventional loan, a three-to-one house price-to-income ratio implies that houscholds need to accumulate an amount equal to 30 percent of one year's gross income to purchase a house. 
The ratio of principal, interest, and tax payments to income exceeded 28 percent (the maximum under Fannie Mae-Freddie Mac Guidelines) in 11 states. If we drop the maximum allowable ratio to 26 percent (to account for mortgage and homeowners insurance), the number of states for which the median renter's income is not sufficient to purchase a house priced at the lowest quartile rises to 15 .

\section{Change in Financial Desirability}

If we use our ex ante measure of user cost, homeowning generally became financially less attractive between 1980 and 1990: the cost of housing services to income ratio rose in $\mathbf{4 9}$ of the 50 states. Two economic phenomena drove this deterioration. First, real interest rates in the late 1980 s were much higher than they were in the late 1970s: from 1977 to 1980 , the rate of house price inflation in many markets nearly matched nominal mortgage interest rates (much less after-tax rates), but from 1987 to 1990, the rate of house price inflation was generally much lower than nominal mortgage rates. Second, the marginal tax rate for the median renter was substantially lower in 1990 than 1980 , largely because of the Tax Reform Act of 1986 . This meant that for itemizers, the mortgage interest and property tax deductions were less valuable in 1990 than in 1980. Indeed, given that so many fewer households itemized at all in 1990 compared with 1980, the deterioration in the financial attractiveness of owner-occupied housing was probably even greater than what we have characterized here (Follain and Ling (1991).' When we look at changes in both the user cost to income ratio and the rent to income ratios, it becomes clear that owning in 1990 was no where near as attractive as it was in 1980.

One aspect of this relationship changes substantially when we look at

- If households itemized in 1980 and did not in 1990, ax ante user cost would have risen in all 50 states. 
the actual cost of the service flow of housing -- that is, when we use an ex post, rather than an ex ante measure. Real interest rates in the early 1980 s were very high by post-War standards: consequently, when we look at the actual cost of owning, 1990 does not look so bad when compared with 1980 -in exactly half the states, the actual cost of owning declined between 1980 and 1990.

\section{E. Summary of Index Results}

Homeownership might not have appeared so attractive in 1990 as a financial investment as it did in 1980: this may explain in part the stagnant homeowning rate. But it is equally clear that affordability conditions for the "typical" first-time buyer improved: in 30, 42 and 47 states, respectively, rentto-income ratios, house price-to-income ratios, and payment-to-income ratios fell between 1980 and $1990 . .^{10}$ We should also note that the households investigated here (those at the median income level for renters) are likely not at the margin of homeownership. When we base the above calculations on renters at the 75th percentile of renter household income, we find that the homeowning opportunities improve even more than for those at the median. One would be hard pressed to make the case that the decade of the 1980 s brought with it a homeowning "affordability" crisis.

${ }^{10}$ Participants at the NBER summer workshop suggested calculating these affordability measures using the median incomes of married couple renters where the head was under the age of 35. The reason for doing this is that several commentators (e.g. Hendershott (1988)) and Myers et al (1992). have underscored the declining homeownership rate among young married couples as an indicator that the homeownership rate might decline further in the future. When I calculated the index using the median incomes of young married renters, the results were basically the same: that affordability conditions generally improved between 1980 and 1990 . For instance, in the case of house-price-to-income ratios, conditions improved for these households everywhere except for five New England states and Maryland. 
If the affordability measures listed above truly reflect liquidity constraints, we would expect them to help predict homeownership rates for the states.

As a rough measure of the relationship between the affordability measures and state homeownership rates, I ran the following regressions:

$$
\begin{gathered}
\text { HOR }_{i}=\alpha+\beta_{1} L T 35_{i}+\beta_{2} \text { GESS }_{i}+\beta_{3} \text { MARRIED }_{i}+\beta_{4} B L A C K_{i} \\
+\beta_{5} \text { PERCAPY } \\
+\beta_{6} U C T O R_{i}+\beta_{7} P I T_{i}+\beta_{5} H P Y_{i}+v_{i}
\end{gathered}
$$

where i subscripts the 50 states, HOR is the homeownership rate, LT35 is the percentage of households headed by someone under the age of 35, GE55 is the percentage of households headed by someone 55 years of age or older, MARRIED is the percentage of households headed by married couples, BLACK is the percentage of households headed by an African-American, PERCAPY is real per capita income, UCTOR is the service cost of owner occupied housing to rent ratio, PIT is the principal, interest and property tax to income ratio, and HPY is the house price to income ratio. I ran the regressions for both 1980 and 1990. HPY and PIT are of course highly correlated, so I ran regreasions using both variables and using each variable without the other.

All regressions have reasonable explanatory power, but only the 1980 regressions produce by-and-large sensible results. In the 1980 regressions, states with high rates of married couple households have high rates of homeowning. The coefficients on LT35, GES5, and BLACK are negative, as we would expect, but are not statistically different from zero at the 90 percent level. The service-cost-to rent and liquidity constraint proxies also perform well: in all three regressions, UCTOR is negative and carries a t-statistic in excess of 2.5, and when PIT and HPY are singly, they are also negative and

11 Anne Schnare suggested this section. 
significant.

While the 1990 results continue to be as expoctod for the coefficients on marriod couple households and service-cost-to-rent, the coefficient on BLACK bocomes significant and positive, as do the coefficients on the two liquidity measures when they are used by themselves. In light of the micro-data results that will be presented later, the statistically positive coefficient for African-American households is puzzling. The coefficients on the liquidity constraint measures are just puzzling.

There are two plausible explanations for the positive signs on the house-price-to-income and PITI to income ratios. First, if high house price markets had speculative bubbles, we will see more people entering the ownership market than we should (see Case and Shiller (1989) and Abraham and Hendershott (1995) for evidence of inefficient housing markets). Such entrance was only possible for the second reason: savings and loans with negative equity were allowed to originate mortgages in the middle-to-late 1980 's. Consequently, many borrowers had a temporary opportunity to borrow under liberal underwriting constraints conditions (e.g. no-documention or lowdocumentation loans). This short-term phenomenon could well have confounded the 1990 regression results.

Ideally, we would run regressions already performed on levels on ten year differences as well. For such a regression to have meaning, however, the coefficients must remain stable over time. We know that this in fact did not happen.

III. A model of choice of household type

A. Introduction

Hendershott (1988) established that household type is an important determinant of homeowning. His paper focussed specifically on marital status, 
and suggested that demographic and social changes have lead to an increasing number of households headed by singles, and that such households are far more likely to rent than households headed by married couples.

We may expand our exploration of how household type affects tenure choice a bit by also looking at the presence of children: presumably, married couples with children are, all else being equal, more likely to purchase a home than married couples without children. Figure 8 , which presents tenure status in 1980 and 1990 by household type and age of head, tends to support this view. So in examining the dynamics of tenure choice, we must also examine the dynamics of the formation of households types. To make things manageable, I divide households into four types: those headed by married couples with no children, those headed by marrieds with children, those headed by singles without children, and those headed by singles with children.

To the extent changing demographics and social values produce changes in household arrangements, which in turn produce changes in the likelihood of owning, we may conclude that the flat homeownership rate does not reflect a paucity of economic opportunity. On the other hand, changing household arrangements could in part reflect changing economic conditions. If this is true, then these less desirable conditions are partly responsible for the flat homeownership rate.

Thus to determine the impact of demographics and economics on the homeownership rate, we should look at the tenure choice decision as the second choice in a sequential choice process: first agents determine what sort of household they will belong to, and then they determine tenure. To simply make household type an explanatory variable in a model of tenure choice would deprive us from finding out the true cause of the changing homeownership rate. It also would present us with endogeneity problems: the choice of household type is clearly "caused" by many of the same variables that determine tenure choice. 
To model the household choice decision, I follow Deaton and

Muellbauer (1980), and

assume a utility function of the form

$$
\left.u=v\left(h\left(\sum_{i=1}^{r} \theta_{i} q_{1}\right), q_{2}, . ., q_{n}\right)\right)
$$

where $\mathrm{u}$ is utility, $\mathrm{h}$ reflects the mapping of the choice of household type into a good, and the $q_{i} s$ represent different goods, and $q_{\mu l}$ 's represent different household types.

If we let $h$ take the form:

$$
h=\sum_{i=1}^{r} \theta_{i}\left(b_{i}, a, \epsilon_{i}\right) q_{11}
$$

where a represents household characteristics and the $b_{i}$ 's represent the characteristics of each household type, then Deaton and Muellbauer show that we can model the household type decision as a multinomial logit. The multinomial logit model allows us only to determine the parameters for $n-1$ of the $n$ possible choices; only by restricting the coefficient estimates for one of the choices to zero may we be sure that the sum of the probabilities for each choice will sum to one for each household. 
A model of household type choice inevitably must contain explanatory variables that are themselves endogenous. For example, income clearly has an impact on the decision to form into various household types ("we'll have children once we're financially ready to do so.") Yet it is also certainly the case that household type affects income level. Consequently, I use a two step procedure in which I fit a reduced form equation for income, and then use the fitted values resulting from that equation in the multinomial logit model of household type choice.

Sex of household head is, to a certain degree, also "endogenous." The teenage girl who has children without marrying is likely the product of a certain type of economic environment. On the other hand, the sex of household head is clearly an important determinant of household type: households headed by singles with children are nearly four times more likely to be headed by women then men (1990 PUMS data).

A natural approach to dealing with this issue might be to use exogenous variables to model the likelihood that the head of household will be female, and then use fitted probabilities from that model as an explanatory variable in the models of household choice type. A simultaneous equation model where all dependent variables are dichotomous is developed in Mallar (1977), and would seem to fit the bill here. Unfortunately, in Mallar (1975), the standard errors of the coefficients on the models actually estimated are quite large; moreover, for reasons discussed in Maddala (1983), the number of 
identifiable parameters in such models is quite small, and the interpretation of the parameters is quite convoluted. Therefore, I simply estimate models excluding the sex of the household head: this allows us to step around the endogeneity problem altogether. As we shall see, even when we exclude this variable, we still obtain plausible predictions about changes in household types between 1980 and 1990.

\section{B. Data, Estimation Model and Results.}

Data come from 7624 households from the 1980 Public Use Micro Survey of the census, and from 9209 households from the 1990 PUMS (i.e., the 1 in 10,000 samples). Households are, as already noted, divided into four types: married without children, married with children, single without children, single with children. Explanatory variables for estimating models explaining income are dummy variables for age of household head, with the age categories being less than $25,25-29,30-34,35-44,45-54,55-64$, and 65-74 (75 and over is the left-out variable); a dummy variable for whether the head is black; dummy variables for educational attainment, with the categories being non-high school graduate head, high school graduate head, "college but no bachelor's degree" head, and college graduate head (advanced degrees are the left-out variable); in one of the models, whether the household head is a woman, whether the household has one earner or two, and finally, regional dummy variables. The regional dummies will help explain differences in houschold 
incomes, but presumably do not "explain" choice of household type; they therefore allow us to identify the second stage multinomial logit equations.

The income equation is estimated using simple OLS (results available on request). The household type choice equations are of course estimated using a multinomial logit model. To identify the logit model, we include number of earners in the income equation, but omit it from the multinomial logit.

The multinomial logit models perform quite well, with sharp parameter estimates and strong goodness of fit measures (see table 2). Married without children is the left-out category. Before discussing how the models predict changes in choice of household type between 1980 and 1990, let us discuss the parameter estimates for each category's logit.

Households with heads aged 35-44 are most likely to be married with children. We also find that relative to the probability of being married without children, those aged 65-75 are less likely to be married with children than those over age 75. This probably reflects the fact that the deaths of spouses are sharply reducing the number of households headed by childless married coupled as the age of head rises from 65 to above 75 . These results are consistent for both the 1980 and 1990 samples.

Also consistent is the impact of education; as educational attainment rises, so by and large does the probability of being married with children relative to the probability of being married without children. Perhaps 
surprising is the outcome that higher income couples are more likely to remain childless: this likely reflects that fact that households often drop from having two earners to one after children enter the picture. ${ }^{12}$

The impact of race changed between 1980 and 1990; in 1980, households headed by blacks were no more or less likely to be marrieds with children relative to marrieds without children; in 1990 , households headed by blacks were less likely to be marrieds with children.

The probability of being a household headed by a single parent reached its peak between the ages of 35 and 44 in both 1980 and 1990. The reason for this is straightforward. In 1980, children of single parents were 11 times more likely to have a divorced or separated mother than a never-wed mother, in 1990, such children were three times as likely to have a divorced or separated mother (sec Current Population Reports). Not surprisingly, as fitted income rises, the probability of "choosing" to be a single parent household falls. Households headed by blacks are more likely to be single parent households; in 1980 , the effect of education on the probability of heading such a household was mixed; in 1990, it was unambiguous: as education rose, the probability of being a single parent also rose. Perhaps this suggests that divorce is more acceptable culturally to the better educated.

${ }^{12}$ Hauren, Hendershott, and Wachter (1995) show that hours worked by females jumps in the year households buy, but then tend to fall from this highpoint sometime thereafter. 
The biggest change in logit coefficients between 1980 and 1990 were in those age coefficients that predicted the probability of being single without children relative to the probability of being married without children. In 1980, the probability of being single relative to the probability of being married and childless rose until age $35-44$, after which it fell. This suggests that the number remaining or becoming single rose with age more rapidly than the number of marrieds who remained childless. In 1990, on the other hand, the number of singles relative to the number of childless marrieds fell until age 65 . This suggests an upward shift in the percentage of married couples who choose to remain childless. We also see shifts in the impact of income (higher income predicts a lower probability of being single in 1980 , and a higher probability in 1990) and education (in 1980, the predicted probability of being a childless single rises and then falls with educational attainment; in 1990 the predicted probability just falls). In both years, households headed by blacks are more likely to be childless singles relative to being childless marrieds than other households.

We use these coefficients to perform the following policy experiments. First, we ask how the composition of household types would change assuming that the 1980 coefficients remained constant, but allowing the demographic distribution of the country to change as it in fact did between 1980 and 1990. We leave income constant at its 1980 level, so we can determine the impact of demographic changes alone. Specifically, we calculate fitted probabilities for 
each household in our sample for the years 1980 and 1990, and find how the average probability of belonging to each household type changed between 1980 and 1990.

Second, we hold 1980 demographic characteristics constant and get fitted values based on the 1980 and 1990 coefficients. This will tell us how "changing tastes" have affected changes in household composition.

Next, in the spirit of Hendershott (1988), note that the proportion of total households that are homeowners of household type $x_{j}$ is just the fraction of the households that belong to type $x_{j}$ multiplied by the household type specific ownership rate $o_{\mathrm{j}}^{\mathrm{x}}$. Thus the predicted change in the ownership rate arising from changes in the composition of household types can be written as

$$
\partial O=\sum_{j=1}^{4} o^{x_{j}} \partial x_{j}
$$

where the large $O$ represents the overall ownership rate. When holding "tastes" constant and changing demographics, we can write

$$
\partial x_{j}=\frac{1}{n} \sum_{i=1}^{n} x_{1980, j}\left(X_{1990, i}\right)-\frac{1}{m} \sum_{k=1}^{m} x_{1980, j}\left(X_{1980, \ell}\right) .
$$

Now the small $x$ 's subscripted by years represent the choice functions estimated for each household type $x_{i}$ large X's subscripted by years represent the demographic characteristics of each household $i$ in 1980 , and the 
characteristics of each household $\mathrm{k}$ in 1990, and $\mathrm{n}$ and $\mathrm{m}$ represent the sample sizes in 1980 and 1990 respectively. To measure the effects of changing coefficients, let both large X's have 1980 subscripts, and let the first small $x$ be subscripted with 1990 . Of course, the sample size for both terms on the right hand side is now $n$, because we are using the same samples in both parts of the expression.

Changes in the nation's demographic characteristics, holding tastes constant, predict a decline in the percentage of households headed by married couples: specifically, the 1980 model predicts that demographic changes between then and 1980 would induce 0.4 percent reduction in the number of households headed by married couples with children, a 1.0 percent reduction in the number headed by marrieds without children, a 1.0 percent increase in the number of singles with children, and a 0.4 percent increase in the number of singles without children.

The impact of changing tastes is even more substantial: had demographic characteristics remained constant, the changing coefficients would predict a 3.6 percent reduction in the number of marrieds with children, a 3.0 percent reduction in the number of marrieds without children, a surprising 3.6 percent reduction in the number of singles with children, and a dramatic 10.1 percent increase in the number of singles without children.

The homeownership rates based on PUMS calculations for each of these types in 1980 were 81 percent, 80 percent, 48 percent, and 43 percent, 
respectively. If each household type maintained a constant homeownership rate between 1980 and 1990, demographically induced changes in choice of household type alone would explain a decline in the homeownership rate of 0.6 percent. Changes in tastes for household types would explain a reduction of 4.2 percent. Together, then, changes in the composition of household types can explain a reduction of the homeownership rate of 4.8 percent.

IV. Models of Tenure Choice by Household Type.

Having found some important determinants of choice of household type, we now need to find how household characteristics within each type determine tenure choice. Some cross-tabulations can give us initial insights before we model relationships more formally. Specifically, some reasonably clear patterns emerge when we examine:

1. Educational status. The effect of educational status on tenure choice changes with age. Through about age 50, non-high school graduate heads are far less likely than others to be homeowners. At later ages, however, the differential gets smaller, and ultimately, non-high school grad heads are actually more likely to be homeowners than other groups (see figure 9, which has tabulations for married white couples). A natural question is whether this pattern is the result of the fact that even people with little education become less liquidity constrained as they get older, or whether it is the result of the fact that low-skill workers were relatively more highly valued 30 years ago. 
2. Race. Until age 70 , homeownership rates among blacks are substantially lower than whites (see figure 10, which has tabulations for households that are headed by high school graduate married couples). A long literature (see Yinger (1986) for a review and analysis) would suggest that this is in large part the result of housing discrimination; however, the outcome could also be the result of taste differentials.

3. Eamers. Perhaps surprisingly, no absolutely distinct pattern appears as to whether two eamer households are more or less likely than one earner households to be homeowners. For those without kids, young two earner couples were more likely to be owners than one earner couples (see figure 11).

The tenure choice model largely incorporates the ideas of Goodman (1988), and Hendershott and Shilling (1979); its distinction is that it looks at how each type of household makes its tenure choice. To mitigate against potential selectivity bias that would arise if we conditioned on household type before performing the tenure choice logit, I estimate a multinomial logit model for eight household types: homeowning married couples with children, renting married couples with children, homeowning married couples without children, and so on,

To interpret the coefficients, we must compare coefficient magnitudes for each household type for the owning and renting equations. As already noted, the model follows past literature by considering age of household head, 
household income, race of household head, gender of household head, and education level of household head to explain household type. We also use our state-by-state calculations of first-time homebuyer user cost and median gross rent to calculate a service flow cost to rent ratio for each state, and apply the appropriate ratio to each household. This ratio helps explain how the tenure choice decision is affected by purely financial considerations. ${ }^{13}$

The results are much as expected (see table 3). The model predicts the likelihood of being a renter, so the negative signs on income for all four household types imply that higher income households are more likely to be homeowners than lower income households.

Similarly, we find a secular relationship between age of household head and likelihood of being a homeowner in all four cases between the ages of 25 and 65: as heads age, they are more likely to become homeowners. The leftout variable represents heads over age 75 . In some instances, the homeownership rate declines after age 65 , in others, after age 75 . This could at least be partially explained by the capital gains exemption on homes sold after age 55 , and partially by the needs of people to move into assisted living rental

13 An earlier iteration of this paper also considered number of earnors as an explanatory variables. This has been dropped becauso of endogeneity problems, and because figure 11 auggests that it doeon't toll us a lot about homeownership rates. And indeed, in the earlier versions, the coefficients on number of eamers were generally not significant. 
housing..$^{14}$

Houscholds headed by blacks are usually far less likely to own their own homes than households headed by whites. This may be a result of the often replicated finding that blacks must spend more for comparable housing than whites (see Yinger (1979) for a review. But also see Follain and Malpezzi (1981), which shows blacks are more liquidity constrained from purchasing housing than whites).

Education appears not to be a particularly important determinant of tenure, except in a few instances. For married couples without children, we get the rather perverse result that households headed by high school graduates are more likely to be homeowners than households headed by people with some post-high school education. Moreover, within this household type, households headed by people with post-graduate degrees are less likely to be homeowners than anyone else. On the other hand, for singles both with and without children, households headed by non-high school graduates are far more likely to rent than others.

The impact of the cost-of-service-flow-to-rent ratio is qualitatively and quantitatively similar across household types, as we would hope. In all four instances, as owner-occupancy becomes less attractive than renting, the predicted probability that one will buy a home falls. Nevertheless, the

14 This is distinct from group home living; poople living in group homes are not included in the data sets used in this paper. 
coefficients on these terms are often not significant at the 90 percent level of confidence.

Once again, we looked at the distribution of demographic variables (age, race, education, and gender of household head for 1980 and 1990), and used them to get fitted tenure choice probabilities for 1980 and 1990 . For three household types -- married couples with and without children, as well as singles without children -- the model predicts that changes in demographics should have led to an increase in the homeownership rate. The model predicts that homeowning should have risen 1.0 percent for married couples both with and without children, and 2.0 percent for singles without children. The model also predicts, however, a decline in the homeownership rate of 0.8 percent among households headed by single parents between 1980 and 1990 owing to a decline in the age of the average head of the single parent household, doubtless reflecting the increase in the number of households with a parent who never married relative to the number of households with a divorced parent.

Clearly, the demographically induced increase in homeownership within the household categories was not large enough to offset the change in the composition of household categories; when one adds the worsening financial attractiveness of owner occupied housing, only a sharp change in tastes toward homeowning could explain a flat, rather than declining, homeownership rate.

And so it was: holding demographics constant, changing tastes would predict a 3.3 percent increase in the ownership rate among marrieds with 
children, a 0.4 percent increase in the rate among marrieds without children, and a large 7.5 percent increase in the rate among singles without children. The predicted rate for singles with children, however, fell by a large 7.7 percent.

\section{Summary and Conclusion}

We have investigated four influences on the homeownership rate in the United States between 1980 and 1990: demographically induced changes in household types, changes in the tastes for household types, demographically induced changes in the demand for homoowning within household types, and changes in tastes for homeowning within household types. The impacts of these separate changes are summarized in columns (1) through (4) in Table 4. In all cases we have controlled for economic factors (i.e., income and usercost). Column ( 1 ) shows that changing demographics during the 1980 s brought about a modest shift from households headed by married couples toward households headed by singles. Because the ownership rate among singles is roughly 40 percentage points less than the ownership rate among marrieds, this contributed to a decline in the aggregate ownership rate of 0.6 percent.

Tastes for household types changed more dramatically: controlling for everything else, households became more than 10 percentage points more likely to be singles with children in 1990 , both because the divorce rate remained at a 
high level and because the number of never-married parents with children

increased (column 2 of Table 4). This had a profound impact on the ownership

rate: changes in tastes for household types predict a 2.7 percentage point

decline in the percentage of owner-occupied households.

Within household types, we find that changes in demographics and tastes for homeowning tended to boost the overall rate. Column (3) shows that demographics prodicted an increase in the ownership rate for all household types except for singles with children. The increasing percentage of young, never-married household heads within this category explains why demographics would predict a decline. The impact of tastes are summarized in column (4), which shows that singles without children became far more likely to choose ownership during the 1980 s, while singles with children became far less likely to choose ownership. The former was perhaps a function of an increase in the number of "non-traditional" households (i.e., couples living together without a marriage licence). Haurin, Hendershott, and Wachter's (1995) results suggest that such households would have more savings than households headed by one single. The latter is again almost certainly a function of the increasing numbers of such households headed by "never-marrieds."

We also see that among married couples, tastes for owning continued to increase, despite the fact that the ownership rate among young married couples declined between 1980 and 1990 . While married couples may be waiting longer before buying, they are becoming more likely to buy at some 
point in their lives.

We use the shares of each household type from the 1980 public use micro-sample to get the weighted average impact of changes in the demand for owning within household types. We find that the overall impact of these changes pushed up the ownership rate by 3.1 percent between 1980 and 1990 . Combined with the impacts of the prodicted changes in household types, the predicted change in the homeownership rate between 1980 and 1990 as the result of changes in demographics and tastes is -0.2 percent.

The difference between the collective impacts of the four influences above and the actual change in the ownership rate may be attributed to economic changes. Because the ownership rate in fact doclined by 0.2 percent, we might infer that economics had no net impact on the ownership rate between 1980 and 1990.

This outcome almost certainly hides an improvement in homeowning conditions. To this point, we have interpreted the changing coefficients in the demand for homeowning within household types as a reflection of changing tastes. However, because liquidity constraints became less binding between 1980 and 1990, households were better able to own their own homes. All else being equal, then, we would expect to see more households within a type "choose" to be homeowners. That is, the increased "taste" for homeowning could simply reflect the fact that previously constrained households became unconstrained. 
Moreover, we know that ex ante user cost rose substantially between 1980 and 1990 , acting to lower the ownership rate. Therefore, the fact that the net effect of economics on the ownership rate was zero suggests that opportunities must have improved (liquidity constraints must have become less binding) over the course of the decade. This is fully consistent with our index results.

The "housing affordability crisis" did not worsen between 1980 and 1990. The homeownership rate declined a bit because more people chose to remain single (i.e., put off marriage) or become single (i.e., get a divorce). All else being equal, singles buy homes less often than married couples, and there are probably good reasons for this. Unless one takes the view that the homeownership rate must be in excess of some arbitrary amount, the stagnancy over the 1980 s should not be a source of concern.

\section{References Cited}

Abraham, Jesse and Patric Hendershott (1995), Bubbles in Metropolitan Housing Markets, Journal of Housing Reseanch. Forthcoming.

Apgar, William, Denise DiPasquale, Jean Cummings, and Nancy McArdle 
(1991), The State of the Nation's Housing. Cambridge: Joint Center for

Housing Studies.

Becker, Gary (1991) A Treatise on the Family. Cambridge, MA: Harvard

University Press.

Case, Karl and Robert Shiller (1989). The Efficiency of the Market for Single

Family Homes. American Economic Review, 79, pp. 125-37.

Deaton, Angus and John Meullbauer (1980). Economics and Consumer

Behavior. Cambridge: Cambridge University Press.

Follain, James and David Ling (1991). The Foderal Tax Subsidy to Housing and the Reduced Value of the Mortgage Interest Deduction. National Tax

Jourmal, June, 147-168.

Follain, James and Stephen Malpezzi (1981). Another Look at Racial

Differences in Housing Prices. Unan Studies, 18, pp.195-203.

Galster, George (1983). Empirical Evidence on Cross-Tenure Differences in

Home Maintenance and Conditions. Land Economics, 59(1), pp. 107-113. 
Goodman, Alan (1988). An Econometric Model of Housing Price, Permanent Income, Tenure Choice, and Housing Demand. Journal of Uiban Economics, 23, pp.327-53.

Goodman, John, Jr. and John Ittner (1992). The Accuracy of Home Owners' Estimates of House Value. Journal of Housing Economics, 2, 339-367.

Green, Richard and Patric Hendershott (1993). Demographic Factors and Real House Prices. NBER Working Paper No. 4332.

Green, Richard and Michelle White (1994). Measuring the Benefits of Homeowning: Effects on Children. University of Chicago Center for the Study of the Economy and the State Working Paper No. 93.

Greene, William (1992) Limdep Version 6.0 Users Manual and Reference Guide. Bellport, N.Y.: Econometric Software, Inc.

Haurin, Donald, Patric Hendershott, and Susan Wachter (1995) Wealth Accumulation and Housing Choices of Young Households: An Exploratory Investigation. Journal of Housing Reseanch. Forthcoming.

Hendershott, Patric (1988). Household Formation and Homeownership: 
Impacts of Demographic, Sociological, and Economic Factors. Housing

Einance Review, 7, pp. 201-224.

Hendershott, Patric and James Shilling (1982). The Economics of Tenure

Choice, 1955-1979.

Research in Real Estate, 1, pp. 105-133.

Hendershott, Patric and Joel Slemrod (1983). Taxes and the User Cost of

Capital for Owner-Occupied Housing. AREUEA Joumal 10, 375-393.

Linneman, Peter and Susan Wachter (1989). The Impacts of Borrowing

Contraints on Homeownership. AREUREA Joumal, 17, 389-402.

Mallar, Charles (1977). The Estimation of Simultancous Probability Models.

Econometrica 45, pp. 1717-22.

Myers, Dowell, Richard Peiser, Gregory Schwann, and John Pitkin (1992).

Retreat from Homeownership: A Comparison of Generations and the States.

Housing Policy Debate, 3, pp. 945-976.

National Association of REALTORS (1992). The Homebuying Transaction. 
Stegman, Michael (1994). Speech to AREUEA Mid-year Meetings,

Washington, D.C.

U.S. Bureau of the Census (1991). 1990 Housing Hiphlights: United States.

CH-S-1-1. Washington, D.C.: U.S. Bureau of the Census.

U.S. Bureau of the Census (1994)., Housing Vacancies and Homeownership,

Construction Reports, Series H-111.

Van Order, Robert and Anne Schnare (1994) Finding Common Ground.

Secondary Mortrage Markets. pp 1, 15-19.

Yinger, John (1979). Prejudice and Discrimination in the Urban Housing

Market, in Mieszkowski and Straszheim, ed. Current Issues in Urban

Economics. Baltimore: Johns Hopkins University Press.

Yinger, John (1986). Measuring Racial Discrimination with Fair Housing

Audits: Caught in the Act, American Economic Review, 76, pp 881-893.

Zorn, Peter (1989). Mobility-Tenure Decisions and Financial Credit: Do

Mortgage Qualification Reqirements Constrain Homeownership? AREUEA

Journal, 17, pp 1-16. 
Table 1

Simple Homeownership Rate Equations

\begin{tabular}{|c|c|c|c|c|c|c|}
\hline \multirow[b]{3}{*}{ Intercept } & \multicolumn{6}{|c|}{ Regreasion for Census Year } \\
\hline & \multicolumn{3}{|c|}{1980} & \multicolumn{3}{|c|}{1990} \\
\hline & $\begin{array}{c}0.53 \\
(0.26)\end{array}$ & $\begin{array}{c}0.52 \\
(0.27)\end{array}$ & $\begin{array}{c}0.45 \\
(0.28)\end{array}$ & $\begin{array}{c}0.04 \\
(0.26)\end{array}$ & $\begin{array}{c}0.00 \\
(0.25)\end{array}$ & $\begin{array}{l}-0.03 \\
(0.26)\end{array}$ \\
\hline $\begin{array}{l}\% \text { of } \\
\text { Houschold } \\
\text { Heads }<35\end{array}$ & $\begin{array}{r}-0.52 \\
(0.48)\end{array}$ & $\begin{array}{l}-0.51 \\
(0.45)\end{array}$ & $\begin{array}{l}-0.45 \\
(0.46)\end{array}$ & $\begin{array}{l}-0.29 \\
(0.43)\end{array}$ & $\begin{array}{l}-0.29 \\
(0.43)\end{array}$ & $\begin{array}{l}-0.27 \\
(0.44)\end{array}$ \\
\hline $\begin{array}{l}\% \text { of } \\
\text { Household } \\
\text { Heads } 255\end{array}$ & $\begin{array}{l}-0.27 \\
(0.38)\end{array}$ & $\begin{array}{l}-0.26 \\
(0.37)\end{array}$ & $\begin{array}{l}-0.23 \\
(0.37)\end{array}$ & $\begin{array}{l}-0.00 \\
(0.27)\end{array}$ & $\begin{array}{c}0.02 \\
(0.27)\end{array}$ & $\begin{array}{c}0.07 \\
(0.27)\end{array}$ \\
\hline $\begin{array}{l}\% \text { of Black } \\
\text { Heads }\end{array}$ & $\begin{array}{l}-0.14 \\
(0.10)\end{array}$ & $\begin{array}{l}-0.14 \\
(0.09)\end{array}$ & $\begin{array}{l}-0.11 \\
(0.09)\end{array}$ & $\begin{array}{c}0.20 \\
(0.07)\end{array}$ & $\begin{array}{c}0.19 \\
(0.06)\end{array}$ & $\begin{array}{c}0.18 \\
(0.06)\end{array}$ \\
\hline $\begin{array}{l}\text { \% of } \\
\text { Married } \\
\text { Couple } \\
\text { Households }\end{array}$ & $\begin{array}{l}0.92 \\
(23)\end{array}$ & $\begin{array}{c}0.92 \\
(0.22)\end{array}$ & $\begin{array}{c}0.96 \\
(0.21)\end{array}$ & $\begin{array}{c}1.32 \\
(0.25)\end{array}$ & $\begin{array}{c}1.38 \\
(0.23)\end{array}$ & $\begin{array}{c}1.40 \\
(0.25)\end{array}$ \\
\hline $\begin{array}{l}\text { Per capita } \\
\text { Income }\end{array}$ & $\begin{array}{r}-0.005 \\
(0.004)\end{array}$ & $\begin{array}{l}-0.005 \\
(0.004)\end{array}$ & $\begin{array}{l}-0.005 \\
(0.004)\end{array}$ & $\begin{array}{l}-0.001 \\
(0.003)\end{array}$ & $\begin{array}{l}-0.000 \\
(0.003)\end{array}$ & $\begin{array}{c}0.000 \\
(0.003)\end{array}$ \\
\hline $\begin{array}{l}\text { PIT to } \\
\text { Income }\end{array}$ & $\begin{array}{l}-0.20 \\
(0.34)\end{array}$ & $\begin{array}{l}-0.17 \\
(0.07)\end{array}$ & & $\begin{array}{c}0.62 \\
(0.43)\end{array}$ & $\begin{array}{c}0.34 \\
(0.13)\end{array}$ & \\
\hline $\begin{array}{l}\text { House Price } \\
\text { to Income }\end{array}$ & $\begin{array}{c}0.00 \\
(3.81)\end{array}$ & & $\begin{array}{l}-0.019 \\
(0.007)\end{array}$ & $\begin{array}{l}-0.03 \\
(0.05)\end{array}$ & & $\begin{array}{c}0.033 \\
(0.014)\end{array}$ \\
\hline $\begin{array}{l}\text { User Cost to } \\
\text { Rent }\end{array}$ & $\begin{array}{l}-0.10 \\
(0.03)\end{array}$ & $\begin{array}{l}-0.10 \\
(0.03)\end{array}$ & $\begin{array}{l}-0.10 \\
(0.03)\end{array}$ & $\begin{array}{l}-0.24 \\
(0.07)\end{array}$ & $\begin{array}{l}-0.25 \\
(0.07)\end{array}$ & $\begin{array}{l}-0.24 \\
(0.07)\end{array}$ \\
\hline $\mathbf{R}^{2}$ & 0.71 & 0.71 & 0.71 & 0.67 & 0.67 & 0.67 \\
\hline
\end{tabular}

Note: observations are the 50 states. Standard errors in parentheses. 
Table 2

Choice of Housebold Type: Multinomial Logit Regressions PUMS Data

\begin{tabular}{|c|c|c|c|c|c|c|}
\hline & \multicolumn{6}{|c|}{ Logit Regressions for Comass Year } \\
\hline & \multicolumn{3}{|c|}{1980} & \multicolumn{3}{|c|}{1990} \\
\hline & $\begin{array}{l}\text { Married } \\
\text { with } \\
\text { Child }\end{array}$ & $\begin{array}{l}\text { Single } \\
\text { with } \\
\text { Child }\end{array}$ & $\begin{array}{l}\text { Single wo } \\
\text { Child }\end{array}$ & $\begin{array}{l}\text { Married } \\
\text { with } \\
\text { Child }\end{array}$ & $\begin{array}{l}\text { Single } \\
\text { with } \\
\text { Child }\end{array}$ & $\begin{array}{l}\text { Single wo } \\
\text { Child }\end{array}$ \\
\hline Age $<25$ & $\begin{array}{l}1.12 \\
(.16)\end{array}$ & $\begin{array}{l}2.33 \\
(.23)\end{array}$ & $\begin{array}{l}1.73 \\
(.16)\end{array}$ & $\begin{array}{l}3.42 \\
(.30)\end{array}$ & $\begin{array}{l}3.57 \\
(.36)\end{array}$ & $\begin{array}{c}.38 \\
(.16)\end{array}$ \\
\hline $\begin{array}{l}\text { Ase } 225 \\
\text { and }<30\end{array}$ & $\begin{array}{l}1.95 \\
(.15)\end{array}$ & $\begin{array}{l}3.45 \\
(.23)\end{array}$ & $\begin{array}{l}2.18 \\
(.16)\end{array}$ & $\begin{array}{l}4.64 \\
(.31)\end{array}$ & $\begin{array}{l}4.32 \\
(.38)\end{array}$ & $\begin{array}{l}. .06 \\
(.14)\end{array}$ \\
\hline $\begin{array}{l}\text { Ase } 230 \\
\text { and < } 35\end{array}$ & $\begin{array}{l}3.01 \\
(.17)\end{array}$ & $\begin{array}{l}4.77 \\
(.25)\end{array}$ & $\begin{array}{l}2.67 \\
(.18)\end{array}$ & $\begin{array}{l}5.63 \\
(.33)\end{array}$ & $\begin{array}{l}5.38 \\
(.40)\end{array}$ & $\begin{array}{l}. .22 \\
(.15)\end{array}$ \\
\hline $\begin{array}{l}\text { Age } 235 \\
\text { and < } 45\end{array}$ & $\begin{array}{l}3.60 \\
(.18)\end{array}$ & $\begin{array}{l}6.09 \\
(.25)\end{array}$ & $\begin{array}{l}2.95 \\
(.19)\end{array}$ & $\begin{array}{l}5.99 \\
(.35)\end{array}$ & $\begin{array}{l}5.62 \\
(.44)\end{array}$ & $\begin{array}{l}-.41 \\
(.13)\end{array}$ \\
\hline $\begin{array}{l}\text { Age } 245 \\
\text { and < } 55\end{array}$ & $\begin{array}{l}1.86 \\
(.18)\end{array}$ & $\begin{array}{l}5.06 \\
(.26)\end{array}$ & $\begin{array}{l}2.19 \\
(.18)\end{array}$ & $\begin{array}{l}4.54 \\
(.38)\end{array}$ & $\begin{array}{l}4.11 \\
(.48)\end{array}$ & $\begin{array}{c}-1.31 \\
(.13)\end{array}$ \\
\hline $\begin{array}{l}\text { Age } 255 \\
\text { and }<65\end{array}$ & $\begin{array}{l}-.11 \\
(.17)\end{array}$ & $\begin{array}{l}3.25 \\
(.23)\end{array}$ & $\begin{array}{l}1.47 \\
\text { (.15) }\end{array}$ & $\begin{array}{l}2.40 \\
(.36)\end{array}$ & $\begin{array}{l}1.39 \\
(.50)\end{array}$ & $\begin{array}{c}-1.43 \\
(.12)\end{array}$ \\
\hline $\begin{array}{l}\text { Age } 265 \\
\text { and < }<75\end{array}$ & $\begin{array}{c}-2.31 \\
(.27)\end{array}$ & $\begin{array}{l}1.18 \\
(.22)\end{array}$ & $\begin{array}{c}.92 \\
(.13)\end{array}$ & $\begin{array}{l}. .63 \\
(.46)\end{array}$ & $\begin{array}{l}-.66 \\
(.57)\end{array}$ & $\begin{array}{c}-1.03 \\
(.10)\end{array}$ \\
\hline $\begin{array}{l}\text { Fitted } \\
\text { Inoome }\end{array}$ & $\begin{array}{l}-.059 \\
(.005)\end{array}$ & $\begin{array}{l}-.245 \\
(.008)\end{array}$ & $\begin{array}{l}-.137 \\
(.006)\end{array}$ & $\begin{array}{l}-.111 \\
(.009)\end{array}$ & $\begin{array}{l}-.167 \\
(.012)\end{array}$ & $\begin{array}{c}.017 \\
(.004)\end{array}$ \\
\hline Black Head & $\begin{array}{l}.14 \\
(.14)\end{array}$ & $\begin{array}{l}.65 \\
(.14)\end{array}$ & $\begin{array}{c}.43 \\
(.12)\end{array}$ & $\begin{array}{l}-.35 \\
(.14)\end{array}$ & $\begin{array}{c}.68 \\
(.15)\end{array}$ & $\begin{array}{l}.90 \\
(.10)\end{array}$ \\
\hline $\begin{array}{l}\text { Non HS } \\
\text { Grad }\end{array}$ & $\begin{array}{l}-.31 \\
(.09)\end{array}$ & $\begin{array}{l}. .63 \\
(.17)\end{array}$ & $\begin{array}{c}.44 \\
(.10)\end{array}$ & $\begin{array}{c}-2.37 \\
(.21)\end{array}$ & $\begin{array}{c}-2.20 \\
(.26)\end{array}$ & $\begin{array}{l}.60 \\
(.07)\end{array}$ \\
\hline HS Grad & $\begin{array}{l}-.15 \\
(.13)\end{array}$ & $\begin{array}{c}.20 \\
(.18)\end{array}$ & $\begin{array}{c}.63 \\
(.11)\end{array}$ & $\begin{array}{c}-2.08 \\
(.18)\end{array}$ & $\begin{array}{c}-2.11 \\
(.24)\end{array}$ & $\begin{array}{c}.44 \\
(.08)\end{array}$ \\
\hline $\begin{array}{l}\text { Attend } \\
\text { College }\end{array}$ & $\begin{array}{l}.09 \\
(.11)\end{array}$ & $\begin{array}{c}.44 \\
(.20)\end{array}$ & $\begin{array}{l}1.11 \\
(.13)\end{array}$ & $\begin{array}{c}-1.78 \\
(.16)\end{array}$ & $\begin{array}{c}-1.49 \\
(.23)\end{array}$ & $\begin{array}{c}.48 \\
(.08)\end{array}$ \\
\hline $\begin{array}{l}\text { College } \\
\text { Grad }\end{array}$ & $\begin{array}{l}-.16 \\
(.13)\end{array}$ & $\begin{array}{c}.75 \\
(.25)\end{array}$ & $\begin{array}{l}1.66 \\
(.16)\end{array}$ & $\begin{array}{c}-1.08 \\
(.13)\end{array}$ & $\begin{array}{r}-1.04 \\
(.25)\end{array}$ & $\begin{array}{l}.21 \\
(.11)\end{array}$ \\
\hline$x^{2}$ & & & 261 & & & 40 \\
\hline $\mathbf{n}$ & & & 24 & & & 09 \\
\hline
\end{tabular}

Note: Asymptotic atandard exrors in parentheacs. 
Table 3.1

Tenure Choice and Hounchold Type Models: 1980 Census PUMS. (Left-out Categary: Married No Child Owner)

\begin{tabular}{|c|c|c|c|c|c|c|c|}
\hline & $\begin{array}{l}\text { Merried } \\
\text { No } \\
\text { Child } \\
\text { Owns }\end{array}$ & $\begin{array}{l}\text { Married } \\
\text { Child } \\
\text { Rents }\end{array}$ & $\begin{array}{l}\text { Marriod } \\
\text { Child } \\
\text { Owme }\end{array}$ & $\begin{array}{l}\text { Single } \\
\text { Child } \\
\text { Rents }\end{array}$ & $\begin{array}{l}\text { Single } \\
\text { Child } \\
\text { Own }\end{array}$ & $\begin{array}{l}\text { Single } \\
\text { No } \\
\text { Child } \\
\text { Owm }\end{array}$ & $\begin{array}{l}\text { Single } \\
\text { No } \\
\text { Child } \\
\text { Rents }\end{array}$ \\
\hline Age it 25 & $\begin{array}{r}-1.62 \\
(.23)\end{array}$ & $\begin{array}{l}1.08 \\
(.26)\end{array}$ & $\begin{array}{l}-.34 \\
(.24)\end{array}$ & $\begin{array}{l}3.11 \\
(.35)\end{array}$ & $\begin{array}{l}. .85 \\
(.41)\end{array}$ & $\begin{array}{l}1.69 \\
(.23)\end{array}$ & $\begin{array}{r}-1.15 \\
(.28)\end{array}$ \\
\hline $\begin{array}{l}\text { Age ge } 25 \\
\text { and it } 30\end{array}$ & $\begin{array}{l}-.98 \\
(.23)\end{array}$ & $\begin{array}{l}2.12 \\
(.27)\end{array}$ & $\begin{array}{l}1.01 \\
(.23)\end{array}$ & $\begin{array}{l}4.35 \\
(.36)\end{array}$ & $\begin{array}{l}1.54 \\
(.31)\end{array}$ & $\begin{array}{l}2.26 \\
(.24)\end{array}$ & $\begin{array}{l}0.31 \\
(.26)\end{array}$ \\
\hline $\begin{array}{l}\text { Age ge } 30 \\
\text { and it } 35\end{array}$ & $\begin{array}{l}-.75 \\
(.28)\end{array}$ & $\begin{array}{l}2.98 \\
(.31)\end{array}$ & $\begin{array}{l}2.36 \\
(.27)\end{array}$ & $\begin{array}{l}5.80 \\
(.40)\end{array}$ & $\begin{array}{l}3.01 \\
(34)\end{array}$ & $\begin{array}{l}2.73 \\
(.29)\end{array}$ & $\begin{array}{l}1.32 \\
(.30)\end{array}$ \\
\hline $\begin{array}{l}\text { Age ge } 35 \\
\text { and } h 45\end{array}$ & $\begin{array}{l}-.46 \\
(.30)\end{array}$ & $\begin{array}{l}3.45 \\
(.34)\end{array}$ & $\begin{array}{l}3.20 \\
(30)\end{array}$ & $\begin{array}{l}7.37 \\
(.43)\end{array}$ & $\begin{array}{l}4.45 \\
(36)\end{array}$ & $\begin{array}{l}3.04 \\
(.32)\end{array}$ & $\begin{array}{l}2.07 \\
(.32)\end{array}$ \\
\hline $\begin{array}{l}\text { Age ge } 45 \\
\text { and ht } 55\end{array}$ & $\begin{array}{l}.51 \\
(.28)\end{array}$ & $\begin{array}{l}2.25 \\
(.36)\end{array}$ & $\begin{array}{l}2.30 \\
(.30)\end{array}$ & $\begin{array}{l}6.80 \\
(.45)\end{array}$ & $\begin{array}{l}4.42 \\
(.36)\end{array}$ & $\begin{array}{l}2.91 \\
(.32)\end{array}$ & $\begin{array}{l}2.38 \\
(.31)\end{array}$ \\
\hline $\begin{array}{l}\text { Age ge } 55 \\
\text { and } 165\end{array}$ & $\begin{array}{l}.70 \\
(.24)\end{array}$ & $\begin{array}{l}.22 \\
(.39)\end{array}$ & $\begin{array}{l}.57 \\
(.27)\end{array}$ & $\begin{array}{l}4.66 \\
(.42)\end{array}$ & $\begin{array}{l}3.12 \\
(.32)\end{array}$ & $\begin{array}{l}2.11 \\
(.28)\end{array}$ & $\begin{array}{l}1.97 \\
(.27)\end{array}$ \\
\hline $\begin{array}{l}\text { Age ge } 65 \\
\text { and hit } 75\end{array}$ & $\begin{array}{l}.41 \\
(.19)\end{array}$ & $\begin{array}{c}-2.07 \\
(.55)\end{array}$ & $\begin{array}{r}-1.90 \\
(.34)\end{array}$ & $\begin{array}{l}1.95 \\
(.41)\end{array}$ & $\begin{array}{l}1.07 \\
(.29)\end{array}$ & $\begin{array}{l}1.33 \\
(.23)\end{array}$ & $\begin{array}{l}1.07 \\
(.21)\end{array}$ \\
\hline $\begin{array}{l}\text { Fitted } \\
\text { Inoome }\end{array}$ & $\begin{array}{l}.04 \\
(.007)\end{array}$ & $\begin{array}{l}-.09 \\
(.009)\end{array}$ & $\begin{array}{l}.01 \\
(.008)\end{array}$ & $\begin{array}{l}-.26 \\
(.01)\end{array}$ & $\begin{array}{l}. .17 \\
.(.001)\end{array}$ & $\begin{array}{l}-.11 \\
(.01)\end{array}$ & $\begin{array}{l}-.12 \\
(.01)\end{array}$ \\
\hline $\begin{array}{l}\text { Black } \\
\text { Head }\end{array}$ & $\begin{array}{l}-.68 \\
(.21)\end{array}$ & $\begin{array}{c}.20 \\
(.22)\end{array}$ & $\begin{array}{l}-.57 \\
(.21)\end{array}$ & $\begin{array}{l}.38 \\
(.21)\end{array}$ & $\begin{array}{l}.02 \\
(.22)\end{array}$ & $\begin{array}{c}.22 \\
(.19)\end{array}$ & $\begin{array}{l}. .44 \\
(.21)\end{array}$ \\
\hline $\begin{array}{l}\text { Non HS } \\
\text { Gred }\end{array}$ & $\begin{array}{c}.96 \\
(.13)\end{array}$ & $\begin{array}{c}.33 \\
(.17)\end{array}$ & $\begin{array}{c}39 \\
(.15)\end{array}$ & $\begin{array}{l}-.94 \\
(.29)\end{array}$ & $\begin{array}{l}.51 \\
(.22)\end{array}$ & $\begin{array}{l}.66 \\
(.16)\end{array}$ & $\begin{array}{l}1.52 \\
(.17)\end{array}$ \\
\hline $\begin{array}{l}\text { HS } \\
\text { Grad }\end{array}$ & $\begin{array}{c}.88 \\
(.14)\end{array}$ & $\begin{array}{l}.17 \\
(.18)\end{array}$ & $\begin{array}{l}.55 \\
(.15)\end{array}$ & $\begin{array}{l}-.13 \\
(.28)\end{array}$ & $\begin{array}{l}1.23 \\
(.23)\end{array}$ & $\begin{array}{l}.69 \\
(.17)\end{array}$ & $\begin{array}{l}1.81 \\
(.19)\end{array}$ \\
\hline $\begin{array}{l}\text { Attend } \\
\text { College }\end{array}$ & $\begin{array}{l}.80 \\
(.17)\end{array}$ & $\begin{array}{l}.07 \\
(.21)\end{array}$ & $\begin{array}{l}.57 \\
(.17)\end{array}$ & $\begin{array}{l}.17 \\
(.30)\end{array}$ & $\begin{array}{l}1.31 \\
(.23)\end{array}$ & $\begin{array}{l}1.12 \\
(.20)\end{array}$ & $\begin{array}{l}2.24 \\
(.22)\end{array}$ \\
\hline $\begin{array}{l}\text { College } \\
\text { Orad }\end{array}$ & $\begin{array}{l}1.06 \\
(.23)\end{array}$ & $\begin{array}{l}.36 \\
(.29)\end{array}$ & $\begin{array}{l}.65 \\
(.23)\end{array}$ & $\begin{array}{l}.69 \\
(.41)\end{array}$ & $\begin{array}{l}1.81 \\
(.36)\end{array}$ & $\begin{array}{l}1.91 \\
(.25)\end{array}$ & $\begin{array}{l}2.97 \\
(.29)\end{array}$ \\
\hline $\begin{array}{l}\text { Uner cost } \\
\text { to Rent }\end{array}$ & $\begin{array}{l}-.03 \\
(.02))\end{array}$ & $\begin{array}{l}-.004 \\
(.02)\end{array}$ & $\begin{array}{l}-.03 \\
(.02)\end{array}$ & $\begin{array}{c}.01 \\
(.02)\end{array}$ & $\begin{array}{l}. .04 \\
(.02)\end{array}$ & $\begin{array}{c}.02 \\
(.02)\end{array}$ & $\begin{array}{l}-.03 \\
(.02)\end{array}$ \\
\hline
\end{tabular}

Note: esymptotic stendand errors in parenthesis, and $n=7624$. 
Table 3.2

Tenure Choice and Hourchold Type Models: 1990 Census PUMS

(Left-out Category: Married No Child Owner)

\begin{tabular}{|c|c|c|c|c|c|c|c|}
\hline & $\begin{array}{l}\text { Married } \\
\text { No } \\
\text { Child } \\
\text { Owme }\end{array}$ & $\begin{array}{l}\text { Married } \\
\text { Child } \\
\text { Rents }\end{array}$ & $\begin{array}{l}\text { Married } \\
\text { Child } \\
\text { Owm }\end{array}$ & $\begin{array}{l}\text { Single } \\
\text { Child } \\
\text { Rent }\end{array}$ & $\begin{array}{l}\text { Single } \\
\text { Child } \\
\text { Owne }\end{array}$ & $\begin{array}{l}\text { Single } \\
\text { No } \\
\text { Child } \\
\text { Renter }\end{array}$ & $\begin{array}{l}\text { Single } \\
\text { No } \\
\text { Child } \\
\text { Owner }\end{array}$ \\
\hline Age 1125 & $\begin{array}{r}-2.79 \\
(.31)\end{array}$ & $\begin{array}{l}2.11 \\
(.42)\end{array}$ & $\begin{array}{l}1.30 \\
(.44)\end{array}$ & $\begin{array}{l}2.10 \\
(.43)\end{array}$ & $\begin{array}{l}1.52 \\
(.71)\end{array}$ & $\begin{array}{l}-.34 \\
(.24)\end{array}$ & $\begin{array}{l}-3.22 \\
(.31)\end{array}$ \\
\hline $\begin{array}{l}\text { Age ge } 25 \\
\text { and th } 30\end{array}$ & $\begin{array}{r}-2.16 \\
(.26)\end{array}$ & $\begin{array}{l}3.18 \\
(.45)\end{array}$ & $\begin{array}{l}3.28 \\
(.44)\end{array}$ & $\begin{array}{l}3.08 \\
(.47)\end{array}$ & $\begin{array}{l}2.50 \\
(.77)\end{array}$ & $\begin{array}{l}-.76 \\
(.25)\end{array}$ & $\begin{array}{l}-2.60 \\
(.26)\end{array}$ \\
\hline $\begin{array}{l}\text { Age ge } 30 \\
\text { and it } 35\end{array}$ & $\begin{array}{r}-1.84 \\
(.28)\end{array}$ & $\begin{array}{l}4.04 \\
(.49)\end{array}$ & $\begin{array}{l}4.65 \\
(.48)\end{array}$ & $\begin{array}{l}4.14 \\
(.51)\end{array}$ & $\begin{array}{l}4.33 \\
(.80)\end{array}$ & $\begin{array}{l}-.85 \\
(.28)\end{array}$ & $\begin{array}{r}-2.37 \\
(.28)\end{array}$ \\
\hline $\begin{array}{l}\text { Age ge } 35 \\
\text { and it } 45\end{array}$ & $\begin{array}{r}-1.31 \\
(.28)\end{array}$ & $\begin{array}{l}4.29 \\
(.53)\end{array}$ & $\begin{array}{l}5.58 \\
(.51)\end{array}$ & $\begin{array}{l}4.54 \\
(.55)\end{array}$ & $\begin{array}{l}5.31 \\
(.87)\end{array}$ & $\begin{array}{l}-.78 \\
(.28)\end{array}$ & $\begin{array}{r}-1.92 \\
(.28)\end{array}$ \\
\hline $\begin{array}{l}\text { Are ge } 45 \\
\text { and lt } 55\end{array}$ & $\begin{array}{l}-.81 \\
(.29)\end{array}$ & $\begin{array}{l}2.91 \\
(.58)\end{array}$ & $\begin{array}{l}4.64 \\
(.55)\end{array}$ & $\begin{array}{l}2.80 \\
(.62)\end{array}$ & $\begin{array}{l}4.81 \\
(.94)\end{array}$ & $\begin{array}{r}-1.55 \\
(.31)\end{array}$ & $\begin{array}{r}-2.11 \\
(.29)\end{array}$ \\
\hline $\begin{array}{l}\text { Age ge } 55 \\
\text { and it } 65\end{array}$ & $\begin{array}{l}. .05 \\
(.27)\end{array}$ & $\begin{array}{l}1.21 \\
(.59)\end{array}$ & $\begin{array}{l}3.20 \\
(.53)\end{array}$ & $\begin{array}{l}-.18 \\
(.88)\end{array}$ & $\begin{array}{l}3.03 \\
(.92)\end{array}$ & $\begin{array}{r}-1.11 \\
(.28)\end{array}$ & $\begin{array}{r}-1.51 \\
(.27)\end{array}$ \\
\hline $\begin{array}{l}\text { A } 8065 \\
\text { and it } 75\end{array}$ & $\begin{array}{l}.28 \\
(.24)\end{array}$ & $\begin{array}{l}-.74 \\
(.73)\end{array}$ & $\begin{array}{l}. .08 \\
(.63)\end{array}$ & $\begin{array}{l}-1.77 \\
(1.09)\end{array}$ & $\begin{array}{l}1.09 \\
(.89)\end{array}$ & $\begin{array}{l}-.88 \\
(.25)\end{array}$ & $\begin{array}{l}-.68 \\
(.23)\end{array}$ \\
\hline $\begin{array}{l}\text { Fittod } \\
\text { Inocme }\end{array}$ & $\begin{array}{l}.06 \\
(.008)\end{array}$ & $\begin{array}{l}-.08 \\
(.01)\end{array}$ & $\begin{array}{l}.07 \\
(.01)\end{array}$ & $\begin{array}{l}-.14 \\
(.02)\end{array}$ & $\begin{array}{l}-.14 \\
(.002)\end{array}$ & $\begin{array}{l}.05 \\
(.01)\end{array}$ & $\begin{array}{l}.07 \\
(.01)\end{array}$ \\
\hline $\begin{array}{l}\text { Black } \\
\text { Head }\end{array}$ & $\begin{array}{l}.17 \\
(.22)\end{array}$ & $\begin{array}{l}.18 \\
(.24)\end{array}$ & $\begin{array}{l}-.56 \\
(.23)\end{array}$ & $\begin{array}{l}.98 \\
(.24)\end{array}$ & $\begin{array}{c}.21 \\
(.28)\end{array}$ & $\begin{array}{l}1.15 \\
(.21)\end{array}$ & $\begin{array}{l}.58 \\
(.22)\end{array}$ \\
\hline $\begin{array}{l}\text { Non HS } \\
\text { Grad }\end{array}$ & $\begin{array}{l}1.11 \\
(.15)\end{array}$ & $\begin{array}{r}-1.14 \\
(.31)\end{array}$ & $\begin{array}{r}-1.91 \\
(.30)\end{array}$ & $\begin{array}{l}-.93 \\
(.33)\end{array}$ & $\begin{array}{r}-2.35 \\
(.52)\end{array}$ & $\begin{array}{l}1.14 \\
(.15)\end{array}$ & $\begin{array}{l}1.51 \\
(.15)\end{array}$ \\
\hline $\begin{array}{l}\text { HS } \\
\text { Orad }\end{array}$ & $\begin{array}{l}1.45 \\
(.16)\end{array}$ & $\begin{array}{r}-1.13 \\
(.30)\end{array}$ & $\begin{array}{r}-1.10 \\
(.27)\end{array}$ & $\begin{array}{l}-.70 \\
(.33)\end{array}$ & $\begin{array}{r}-1.89 \\
(.46)\end{array}$ & $\begin{array}{l}1.10 \\
(.17)\end{array}$ & $\begin{array}{l}1.80 \\
(.17)\end{array}$ \\
\hline $\begin{array}{l}\text { Attend } \\
\text { College }\end{array}$ & $\begin{array}{l}1.30 \\
(.17)\end{array}$ & $\begin{array}{l}. .88 \\
(.27)\end{array}$ & $\begin{array}{l}-.89 \\
(.24)\end{array}$ & $\begin{array}{l}-.42 \\
(.32)\end{array}$ & $\begin{array}{l}-.85 \\
(.41)\end{array}$ & $\begin{array}{l}1.12 \\
(.18)\end{array}$ & $\begin{array}{l}1.67 \\
(.17)\end{array}$ \\
\hline $\begin{array}{l}\text { College } \\
\text { Grad }\end{array}$ & $\begin{array}{l}.78 \\
(.21)\end{array}$ & $\begin{array}{l}. .92 \\
(.27)\end{array}$ & $\begin{array}{l}. .42 \\
(.22)\end{array}$ & $\begin{array}{l}. .48 \\
(.40)\end{array}$ & $\begin{array}{l}-.43 \\
(.37)\end{array}$ & $\begin{array}{l}.72 \\
(.22)\end{array}$ & $\begin{array}{c}.83 \\
(.22)\end{array}$ \\
\hline $\begin{array}{l}\text { User cout } \\
\text { to Rent }\end{array}$ & $\begin{array}{l}-.0002 \\
(.0004)\end{array}$ & $\begin{array}{l}. .0005 \\
(.0005)\end{array}$ & $\begin{array}{l}. .0006 \\
(.0004)\end{array}$ & $\begin{array}{l}.001 \\
(.0005)\end{array}$ & $\begin{array}{l}-.0006 \\
(.0006)\end{array}$ & $\begin{array}{c}.0000 \\
(.0005)\end{array}$ & $\begin{array}{l}-.0003 \\
(.0004)\end{array}$ \\
\hline
\end{tabular}

Note: arymplotic standard errors in parentheses and $n=9209$. 
Table 4

Summary of Demographic and Tate Effects on Owneraip Rate

\begin{tabular}{|c|c|c|c|c|}
\hline & \multicolumn{2}{|c|}{ Prodicted $\Delta$ in Houschold Types } & \multicolumn{2}{|c|}{$\begin{array}{l}\text { Prodicted } \Delta \text { In Demend for Owning } \\
\text { within Houschold Types }\end{array}$} \\
\hline & Demogrephice & "Taste" & Demographio & "Tastes" \\
\hline & (1) & (2) & (3) & (4) \\
\hline $\begin{array}{l}\text { Singles without } \\
\text { Children }\end{array}$ & $+0.4 \%$ & $-3.6 \%$ & $+2.0 \%$ & $+7.5 \%$ \\
\hline $\begin{array}{l}\text { Singlea with } \\
\text { Crildrea }\end{array}$ & $+1.0 \%$ & $+10.1 \%$ & $-0.8 \%$ & $-7.7 \%$ \\
\hline $\begin{array}{l}\text { Married } \\
\text { Couples } \\
\text { without } \\
\text { Children }\end{array}$ & $-1.0 \%$ & $-3.0 \%$ & $+1.0 \%$ & $+0.4 \%$ \\
\hline $\begin{array}{l}\text { Married } \\
\text { Couplea with } \\
\text { Childen }\end{array}$ & $-0.4 \%$ & $-3.6 \%$ & $+1.0 \%$ & $+3.3 \%$ \\
\hline $\begin{array}{l}\text { Overall Impact } \\
\text { on } \\
\text { Ownership } \\
\text { Rate }\end{array}$ & $-0.6 \%$ & $-2.7 \%$ & $+1.0 \%$ & $+2.1 \%$ \\
\hline
\end{tabular}


Table 1

\section{Change in Ratio of Rent to Income 1980-1990}

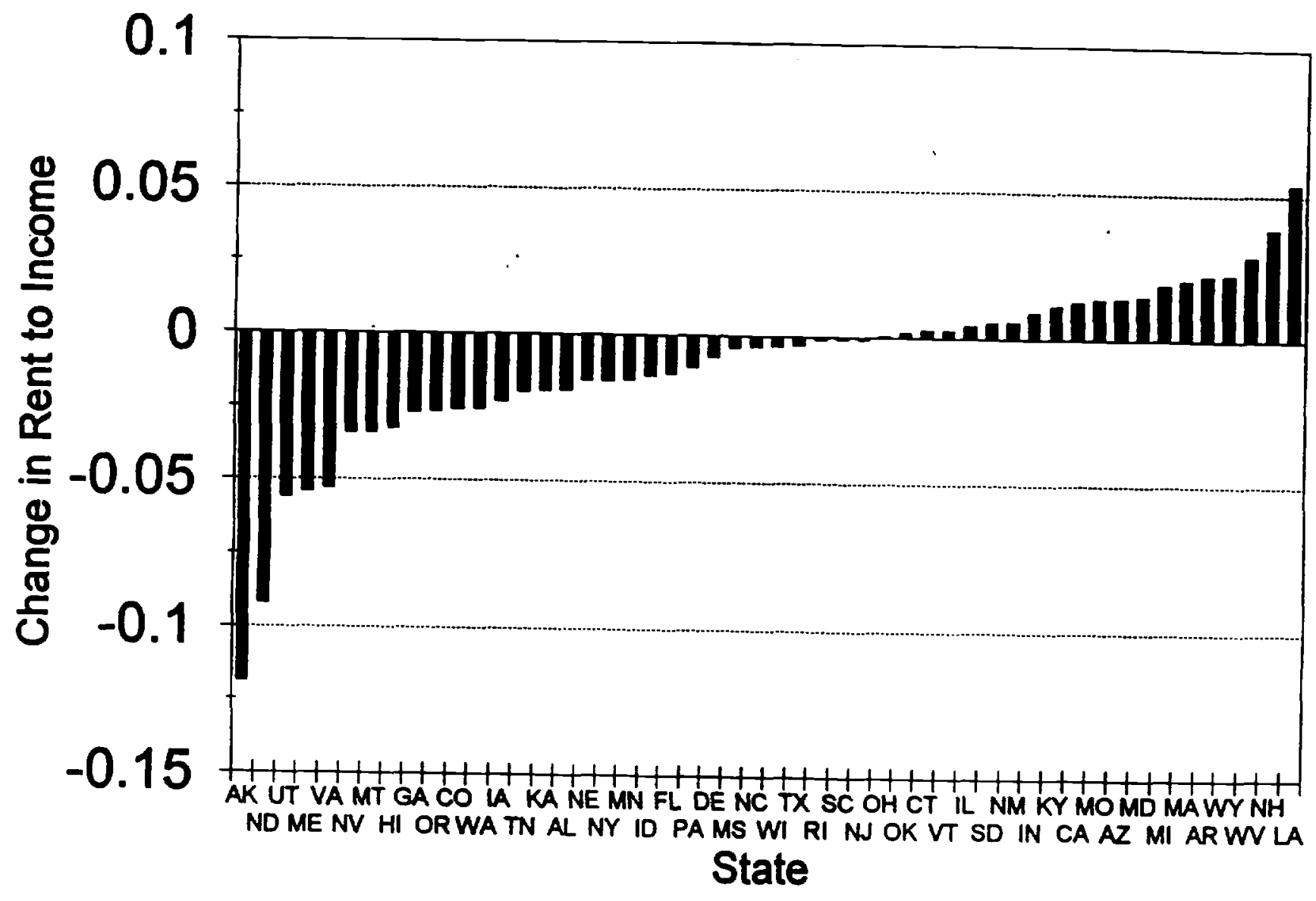


Table 2

\section{Change in House Price to Income Ratio 1980-1990}

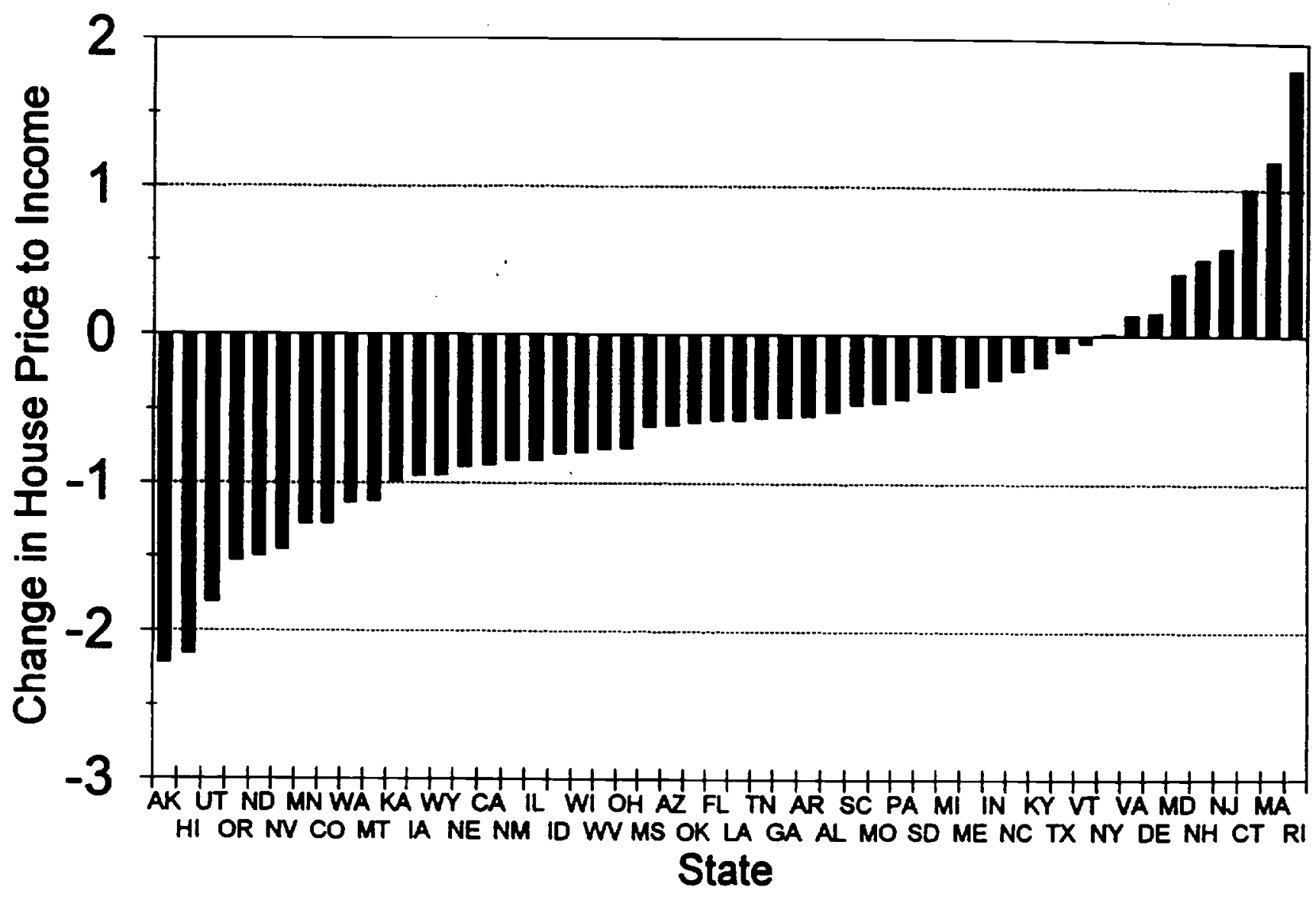


Table 3

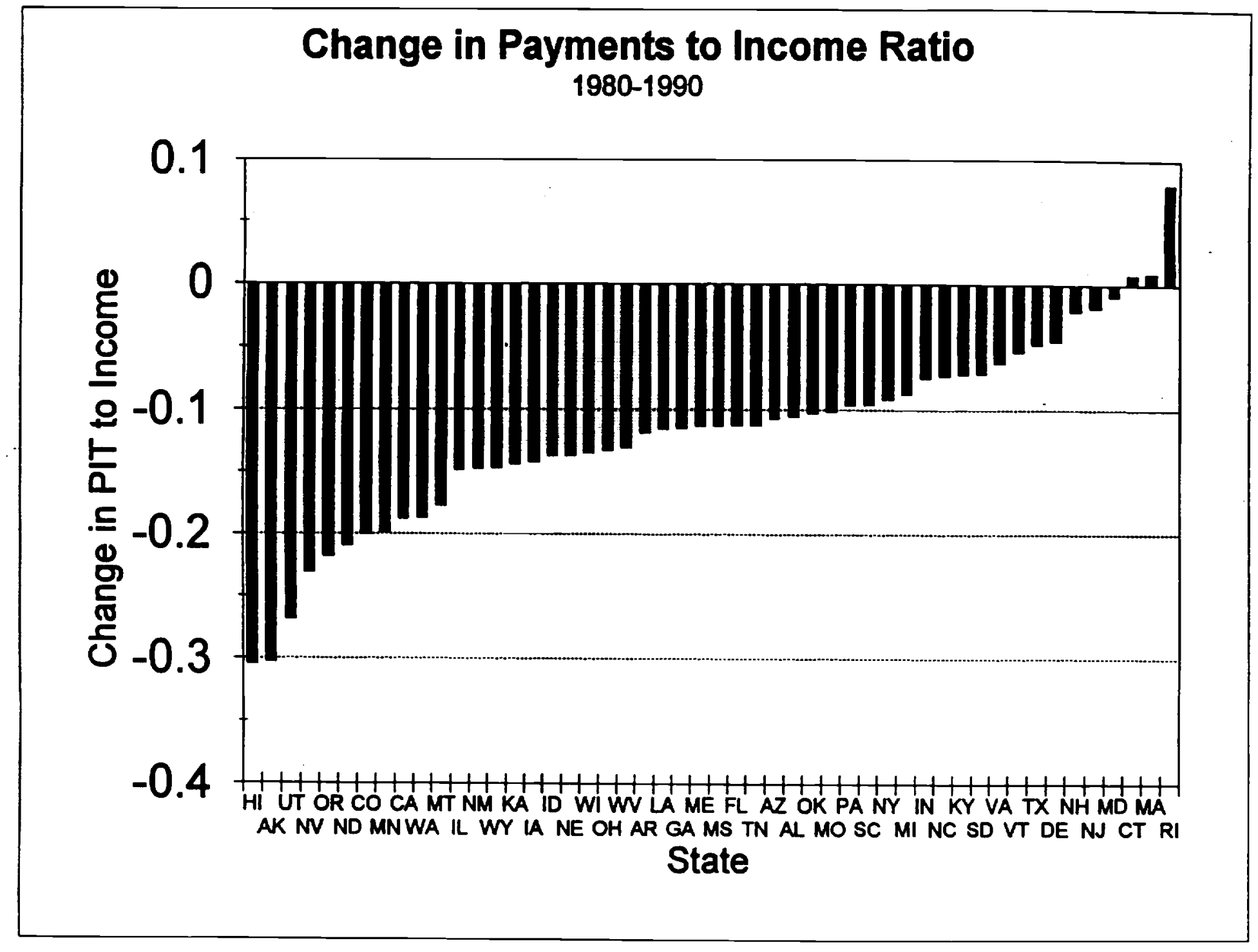


Table 4

\section{Rent to Income Ratio 1990}

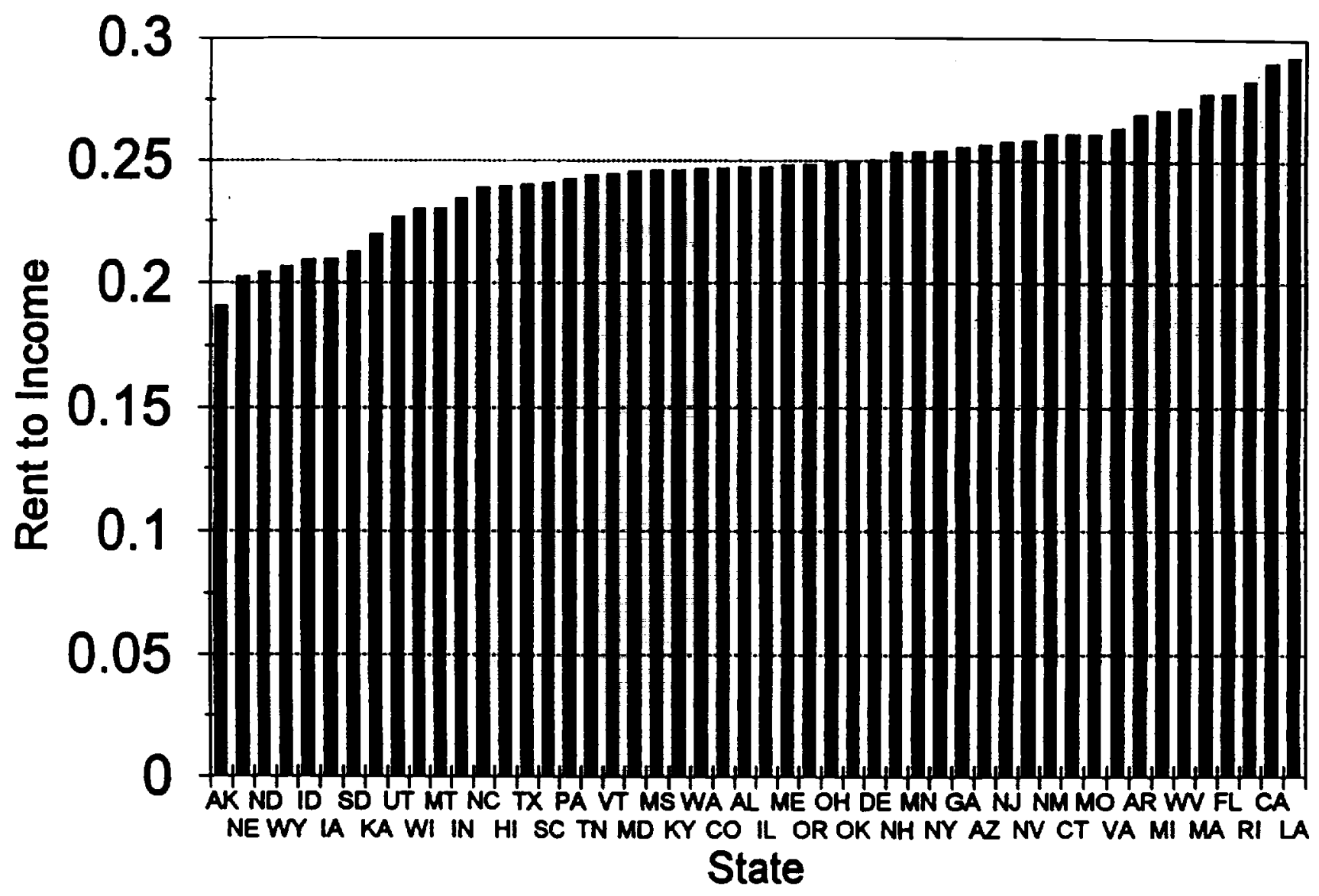


Table 5

\section{House Price to Income Ratio 1990}

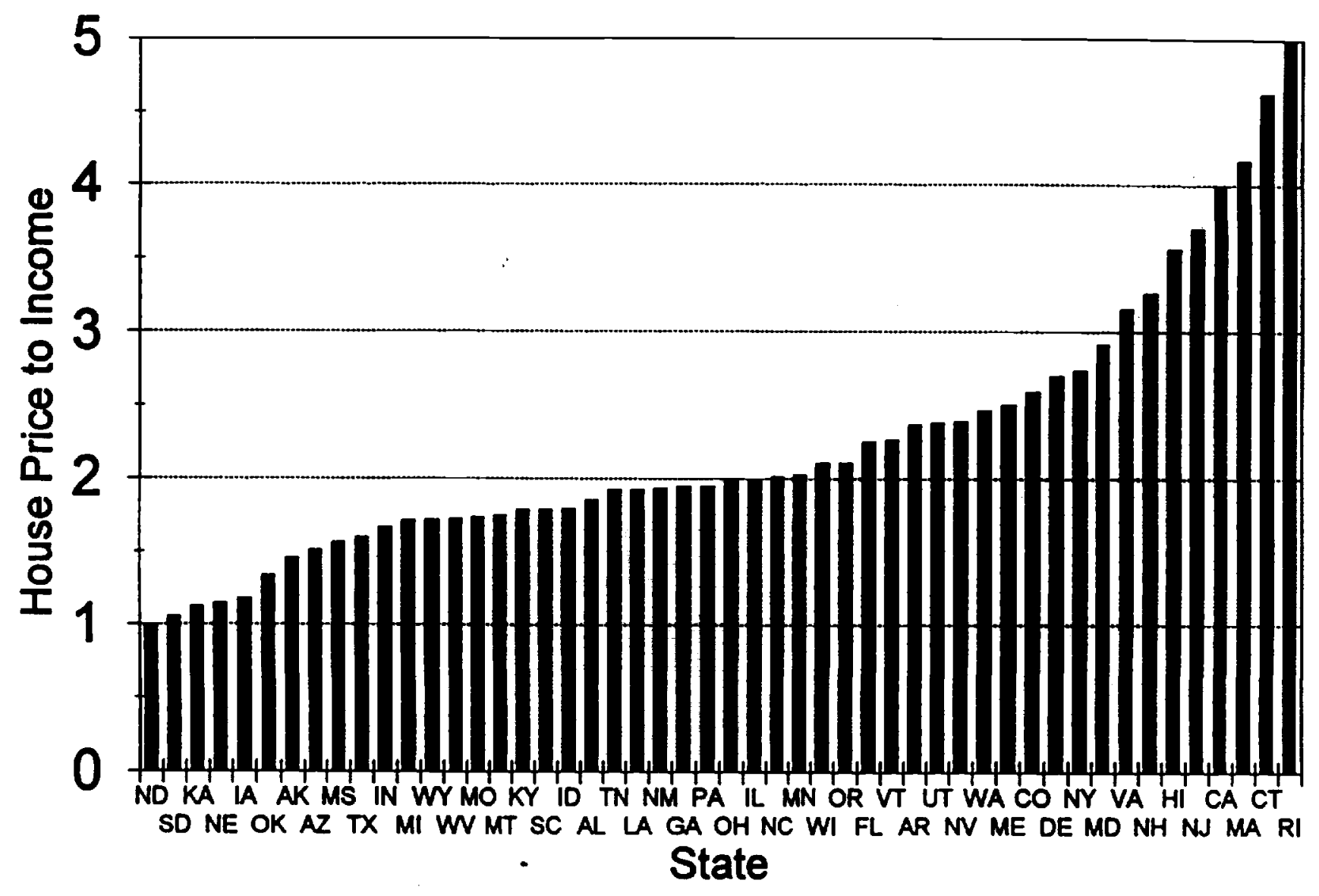


Table 6

\section{Payment to Income Ratio 1990}

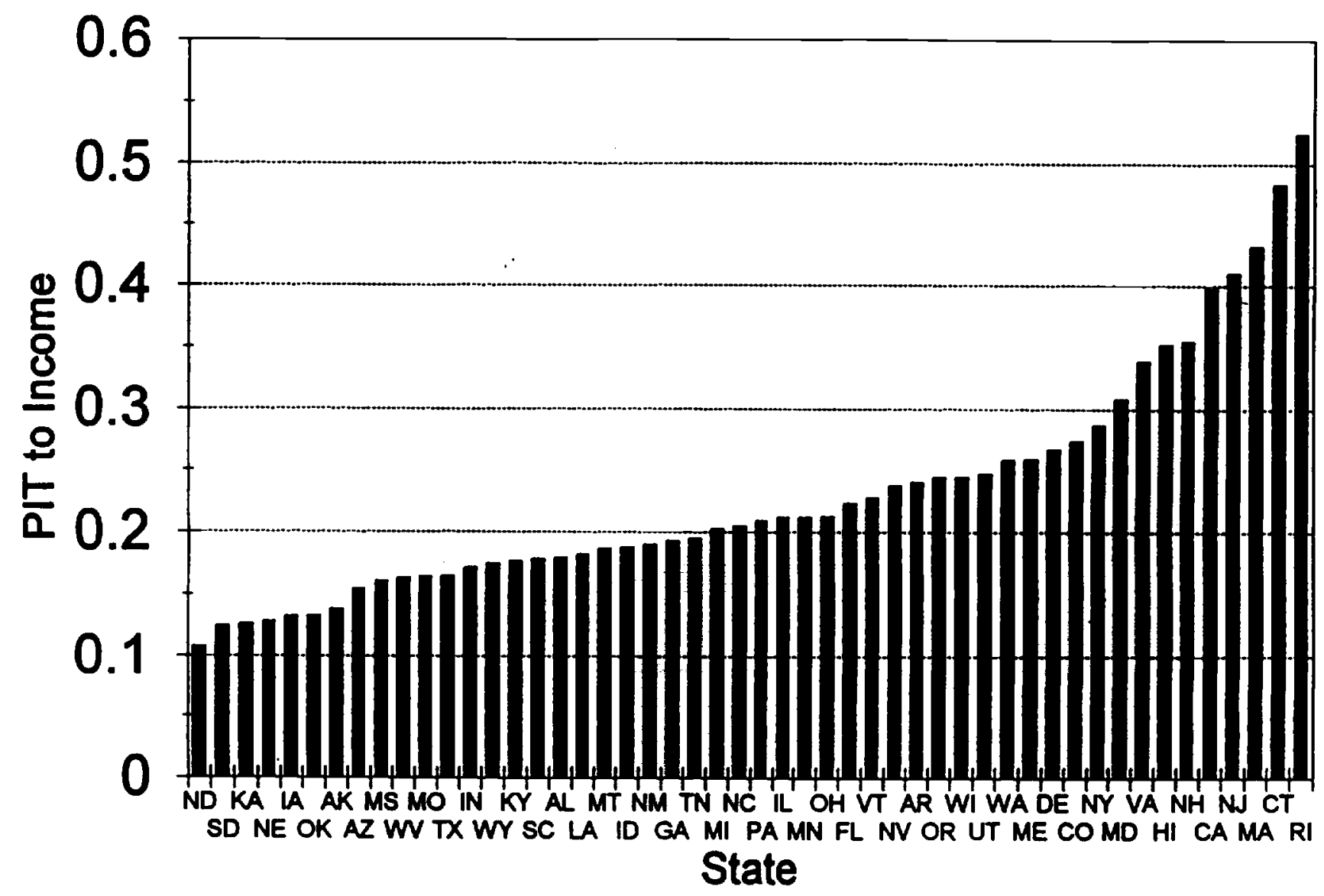




\section{Change in User Cost to Income Ratio 1980-1990}

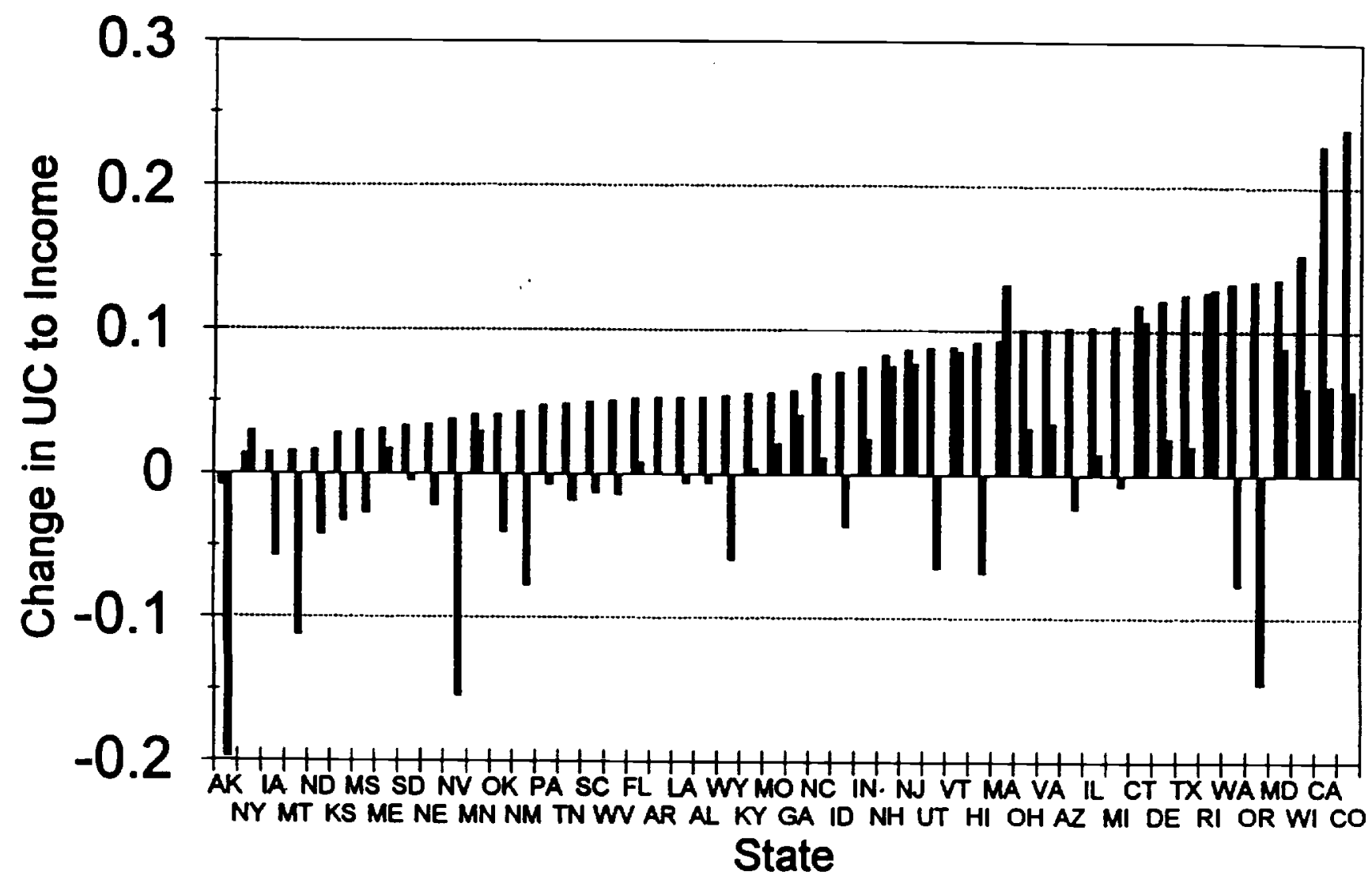


Table 8

\section{Homeownership Rate (1980) \\ By Household Type}

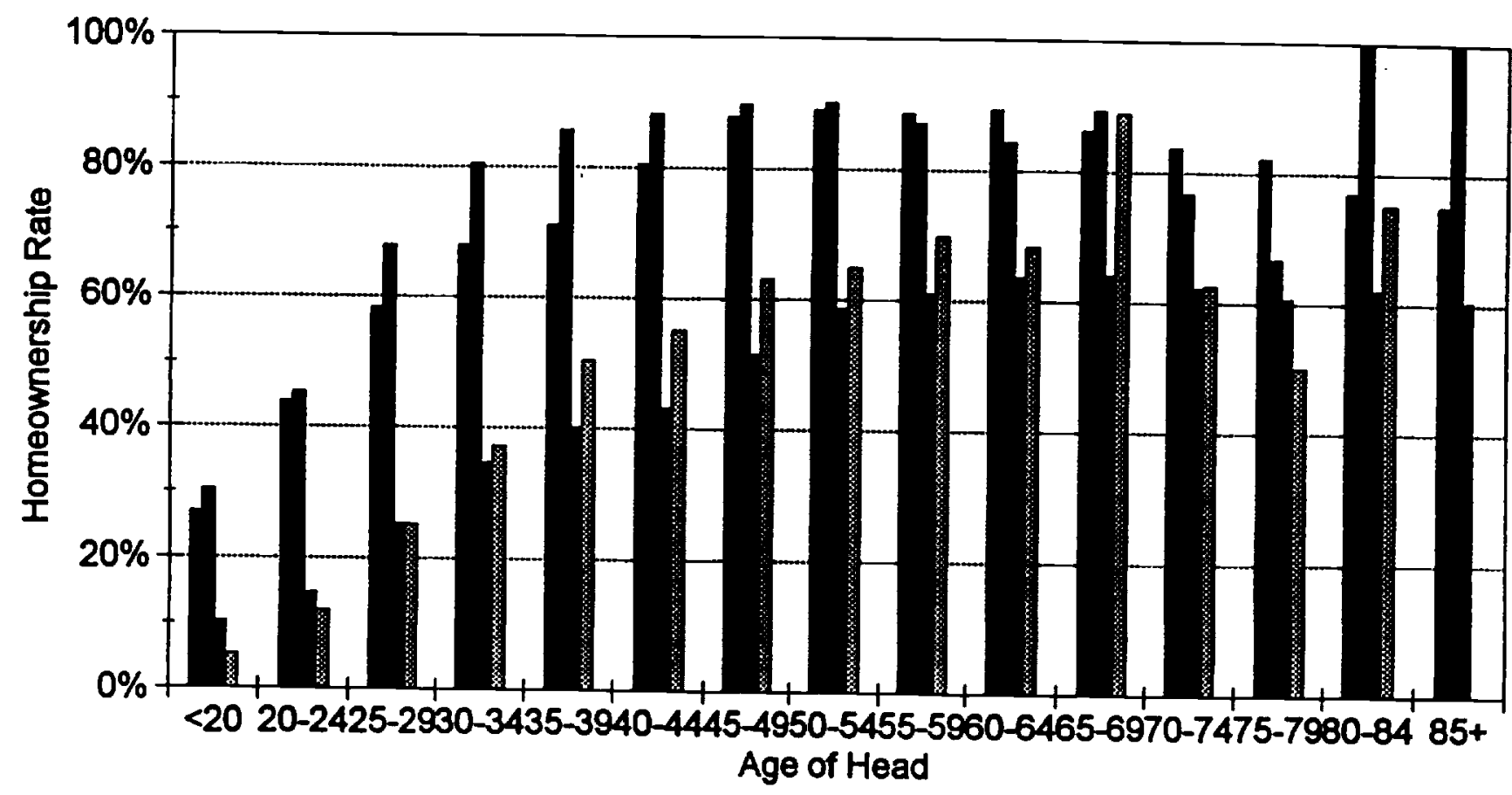

\section{Married no Children Married with Children Single no Children Single with Children}


Table 9

\section{Homeownership Rate (1980) By Educational Status}

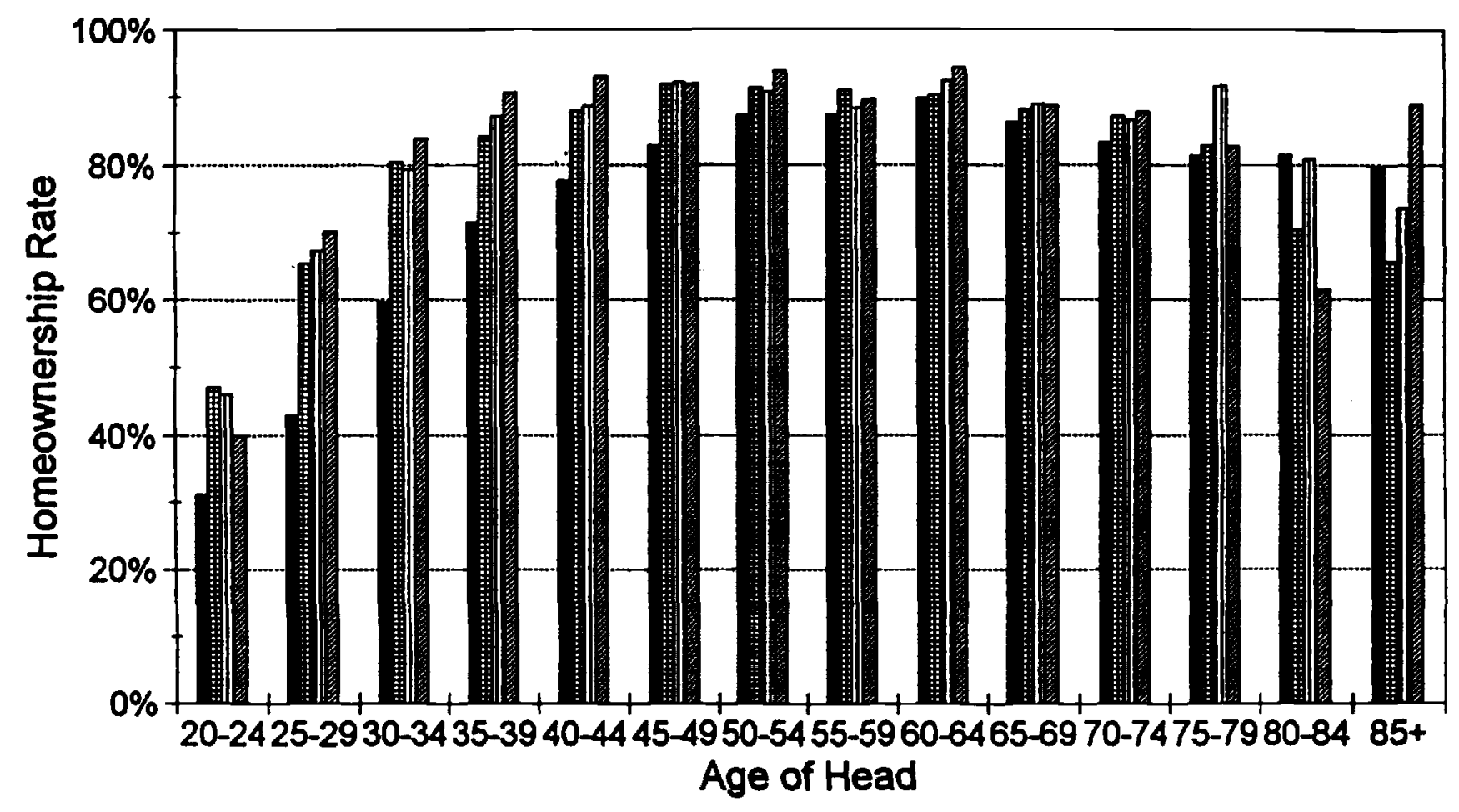

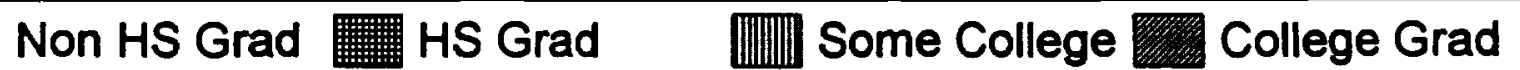


Table 10

\section{Homeownership Rate (1980) by Race}

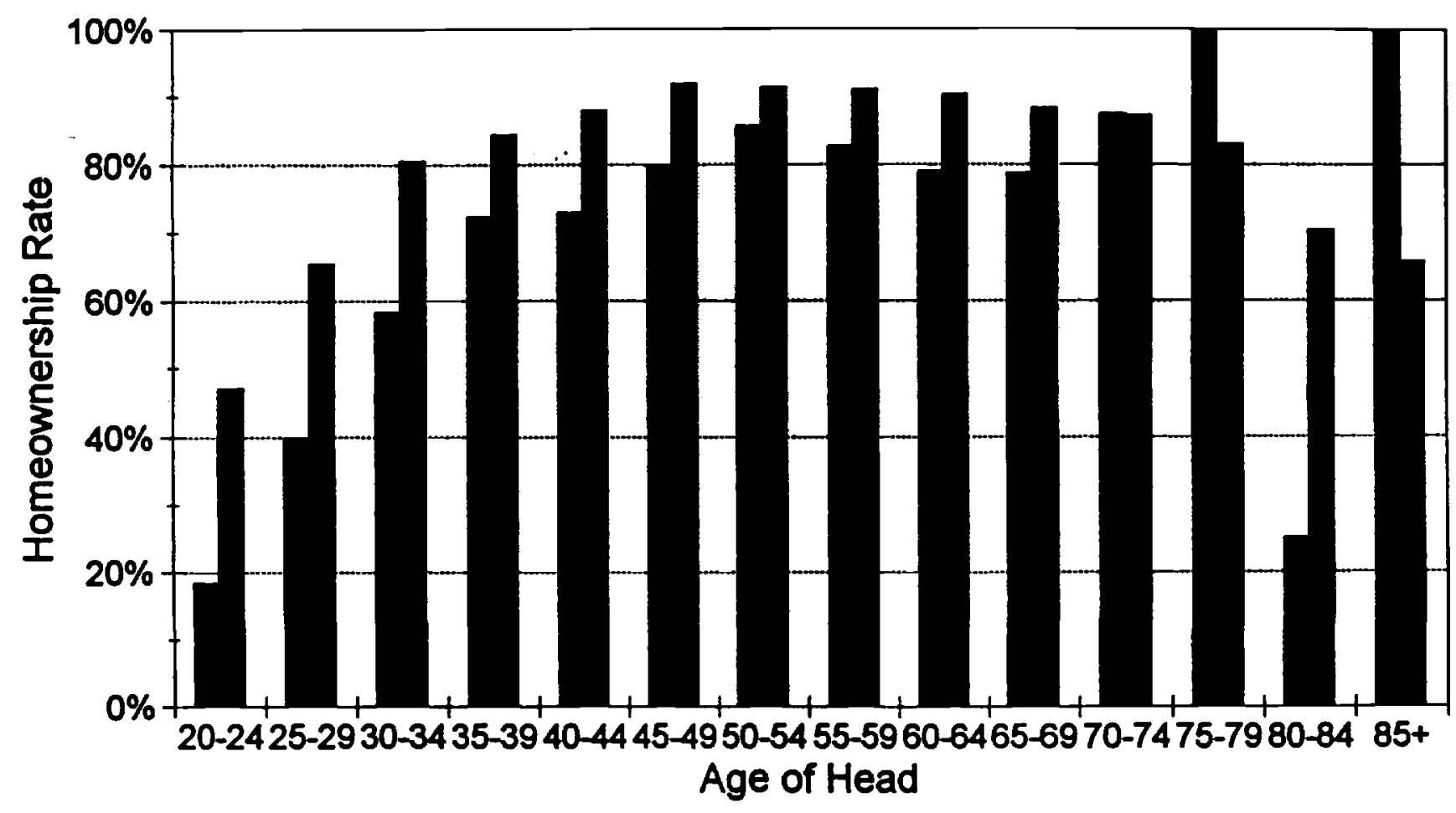


Table 11

\section{Homeownership Rates (1980)}

Earners and Presence of Children

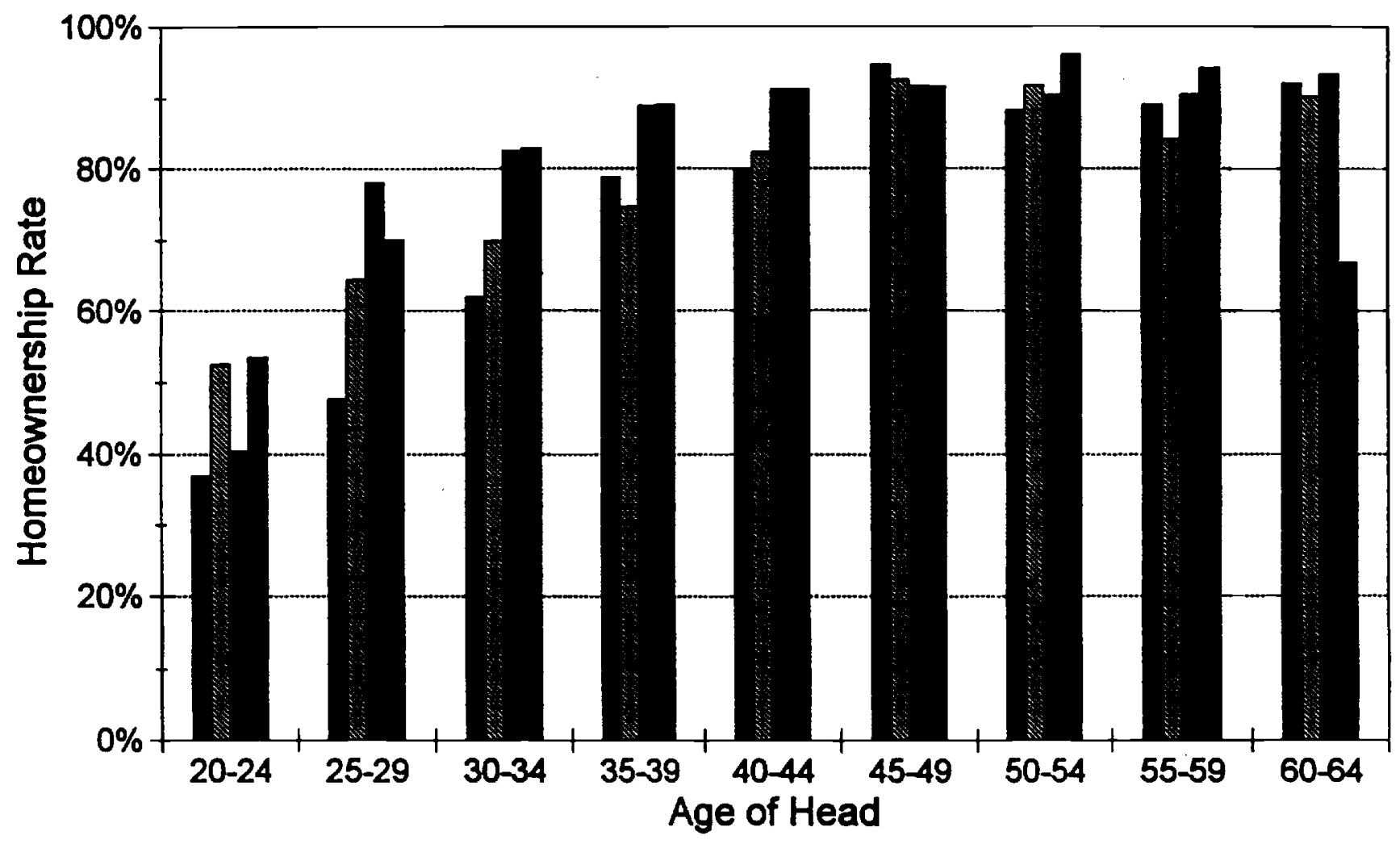
1 Earner No Kids
2 Earners no Kids
1 Earner with Kids 2 Earners with Kids 